\title{
28 Research Square \\ Land Utilization in Indian Cities and The Role of Development Control Regulation: A Case Study of Ahmedabad
}

Renuka Singh ( $\nabla$ renuka.apd@iitbhu.ac.in )

Indian Institute of Technology (BHU) https://orcid.org/0000-0003-3966-1861

\section{Research Article}

Keywords: Land Utilization, Urban Land, Land Efficiency, Public Realm, Private Open Space, Permissible Building Footprints.

Posted Date: March 8th, 2021

DOI: https://doi.org/10.21203/rs.3.rs-301654/v1

License: (9) This work is licensed under a Creative Commons Attribution 4.0 International License.

Read Full License 


\title{
Land Utilization in Indian Cities and The Role of Development Control Regulation: A Case Study of Ahmedabad
}

\author{
Ar. Renuka Singh, \\ Assistant Professor, \\ Department of Architecture, Planning and Design \\ Indian Institute of Technology (BHU) \\ E-mail: renuka.apd@iitbhu.ac.in, \\ ORCID: https://orcid.org/0000-0003-3966-1861 \\ Website: https://iitbhu.ac.in/dept/apd/people/renukaapd
}

\begin{abstract}
:
India's urban population is expected to grow from 410 million in 2014 to 814 million by 2050 , as per the TERI document. If urban growth continues to grow at this rate, to accommodate new urban population, large amount of urban land will be required. With the fact that, the land is an important and limited resource, the need to find the way to use it efficiently and smartly is essential. For that, first step is to understand the existing urban morphology and its impact on land utilization in the current scenario. This will help to understand how efficiently is the urban land utilized in Indian cities, if we compare the study with other world cities. The main concern of the research is - 1. How efficiently is the urban land utilized in India's cities?, 2. What is the role of Development Control Regulations (DCRs) in the efficiency of land utilization?, 3. How utilization of urban land can be improved with respect to DCRs?. For the study, urban land is classified in three parts public realm, building footprints and private open space. To understand the existing urban land, quantitative and qualitative study of it has been taken out for the thirteen squares in Ahmedabad city. From the study it has been found that the majority of land area in our cities falls under the category of private open space, which is primarily divided in small pieces. A further study of private open spaces reveals the existing condition of it utilized or under-utilized. The study questions, why do we need private open spaces in such large amount around the buildings? To understand the argument, a similar study has been under taken to understand how urban land is used in other world cities. Following this, the study takes a new turn to find why we need private open space around the buildings in Indian cities? Is it out of people's choice or they are forced to do so? Does, the development control regulations play an important role in making large amount of private open space?. The research elaborates all the arguments with the existing scenario of Indian city (Ahmedabad as a case) and suggests how we can improve the land utilization through some changes in development control regulations.
\end{abstract}

\section{Keywords:}

Land Utilization, Urban Land, Land Efficiency, Public Realm, Private Open Space, Permissible Building Footprints. 


\section{INTRODUCTION:}

\subsection{Background:}

"Urban population growth requires cities to expand" - (Bertaud, 2010).

India's urban population is expected to grow from 410 million in 2014 to 814 million by 2050, as per the TERI document. There will be a need of more people to accommodate in our cities. On the other side, serviced urban land is becoming increasingly scarce in our cities. Therefore, it is very important to find ways of efficiently using it to accommodate the growing urban population, without reducing the quality of the urban environment (Rosanna $\&$ Chapin, 1957). More efficient use of land would reduce not only the direct cost of land in projects but also the cost of providing and maintaining urban infrastructure (Bertaud et al., 1988).

\subsection{Need of the Study:}

Different urban patterns and urban forms utilize land, as a resource differently (Anguluri \& Narayanan, 2017). These patterns and forms have different types of impacts on its use of land, amount of floor space generated, number of people accommodated (people density), how well organized it feels on ground, etc. Generally, these development patterns and urban forms are direct result of the development control regulations (DCRs) of the city (Adhvaryu, 2011; Thomas et al., 2014). Failure to efficiently use land for the growing population results in high housing prices, exacerbates the creation of high-density slums, and generally lowers urban productivity (Bertaud, 2010). Therefore, there is an urgent need to understand the existing urban morphology and its impact on the land utilization.

\subsection{Aim and Research Questions:}

The aim of this research is to analyze alternative urban dynamics and morphologies of Indian cities and to assess their efficiencies and inefficiencies in the way they utilize their urban land. Also, understanding the impact of regulation on the land utilization and how can we improve it. The aim leads to research questions -

1. How efficiently is the urban land utilized in India's cities?

2. What is the role of Development Control Regulations (DCRs) in the efficiency of Land Utilization?

3. How utilization of urban land can be improved with respect to DCRs?

\section{LAND UTILIZATION IN INDIAN CITIES:}

Land is one of the most important and limited resource, on which all the human's activities are depend upon. The study of land utilization has become crucial in present days, as it helps to find the non-used or miss-used land and also helps to find solutions to reuse that part of land. To study Land Utilization, one needs to classify it as per the study requirement.

\subsection{Classification of Urban Land:}

The classification of urban land is important to understand the complex character of the city structure. For the study purpose, the urban land is divided into three parts Public Realm (public streets and public open space), Building Footprint, and Private Open Space. 


\section{An area in Public Realm:}

Space that is shared communally by people. Public Street and public Open Space are part of the Public Realm.

\section{An area in Building Footprint:}

A piece of land used by the building structure. Parking lots, landscaping, temporary structures, other non-building facilities are not included in the building footprint.

\section{An area in Private Open Space:}

An outdoor area in private property is considered to be a private open space like marginal space, common plots, parking space, internal roads, etc.

\subsection{Site Selection:}

Ahmedabad city has been selected as a case for the land utilization study due to its easy accessibility to the sites. To carry out a detailed study -

a. A sample size of Squares having an area of 25 ha $(500 \mathrm{~m} \times 500 \mathrm{~m})$ has been selected in a different part of the city. Some of the sites are developed at different times and lies in different planning zones, according to Ahmedabad Master Plan 2021.

b. The study area could be selected as per the Transect lines, but transect lines vary from area to area and city to city. Therefore, the land utilization through the transect line would be misleading, as there would be no common factor to relate or compare different sites in the city. Hence, a sample size of the square has been set as a fixed parameter for the study.

c. Square of fixed shape and size $(500 \mathrm{~m} \times 500 \mathrm{~m})$, has been selected as bigger than the selected dimension would have been difficult to manage and finish within the research time limit, and a sample size lesser than the selected dimension

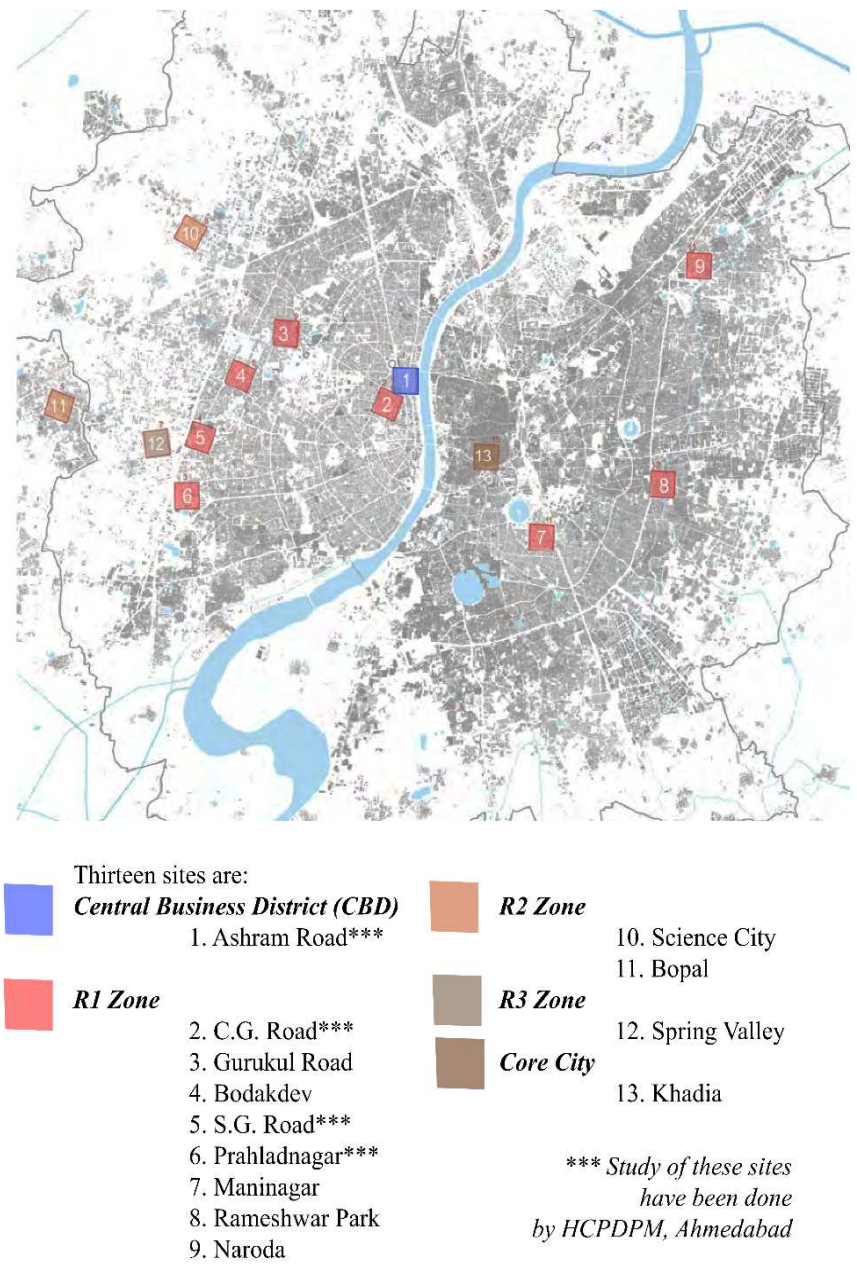

Figure 1. Selected Areas across the Ahmedabad City for the Land Utilization Study. (Source of the Ahmedabad Map - HCP, Ahmedabad) would have been too small to get any solid numbers for thorough study.

Thirteen squares have been selected according to their different urban patterns and along the city's transect lines, i.e., from the oldest core city to the newest peri-urban area, which can be seen in Figure. 1. 


\subsection{Study Process of Sample Squares:}

After the site selection, each site has been digitized using aerial imagery extracted from Google Earth Pro, Figure. 2(i). Google Earth Pro has been chosen for aerial image extraction, as it is easily available, it provides high-resolution images, and it offers worldwide imagery with proper scales. The digitization of each square has been done layerwise, as per the classification of urban land for the land utilization study-

1. Public realm - public street and public open space - Figure. 2(ii),

*Public Open Space - Public Parks, playground, open grounds allocated as per the T.P. Plan.

2. Building Footprint - Figure. 2(iii), and

3. Private Open Space - Figure. 2(iv).

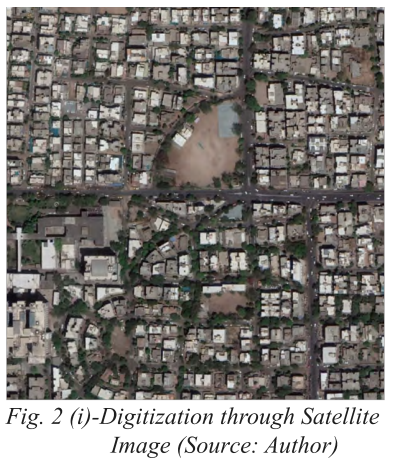

LEGENDS $\square$ Public Street

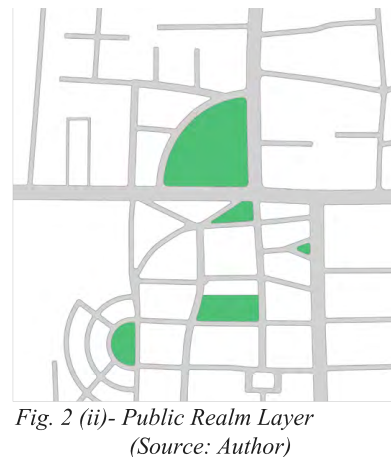

Public Open Space

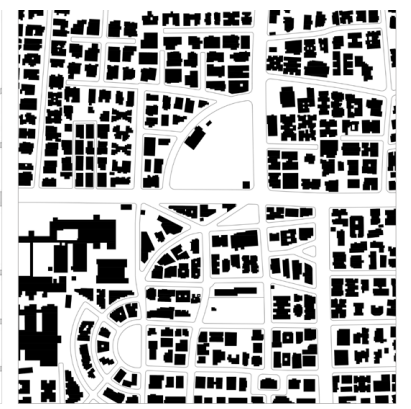

Fig 2 (iii) Builing

(Source: Author)

Building Footprint $\square$ Private Open Space

Figure 2. Layers of the Sample Square (i) Satellite Image, (ii) Public Realm, (iii) Building Footprint, (iv) Private Open Space. (Source: Author)

Then, the area of each layer has been calculated and recorded in the form of a Table. 1 .

Table 1. Format of Quantitative study of the sample squares. (Source: Author)

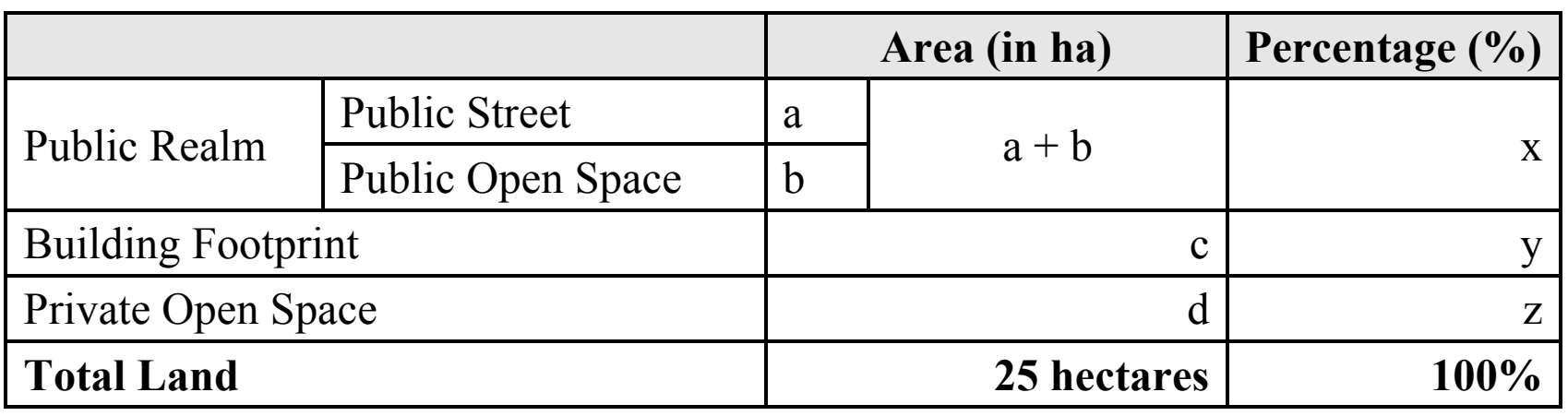




\subsection{Land Utilization Study (Ahmedabad as a Case):}

Comparison of all the Selected Squares (Ashram Road, Prahladnagar, Science City, C.G.Road, S.G.Road, Bopal, Maninagar, Gurukul Road, Spring Valley, Naroda, Bodakdev) is shown in Figure. 3.

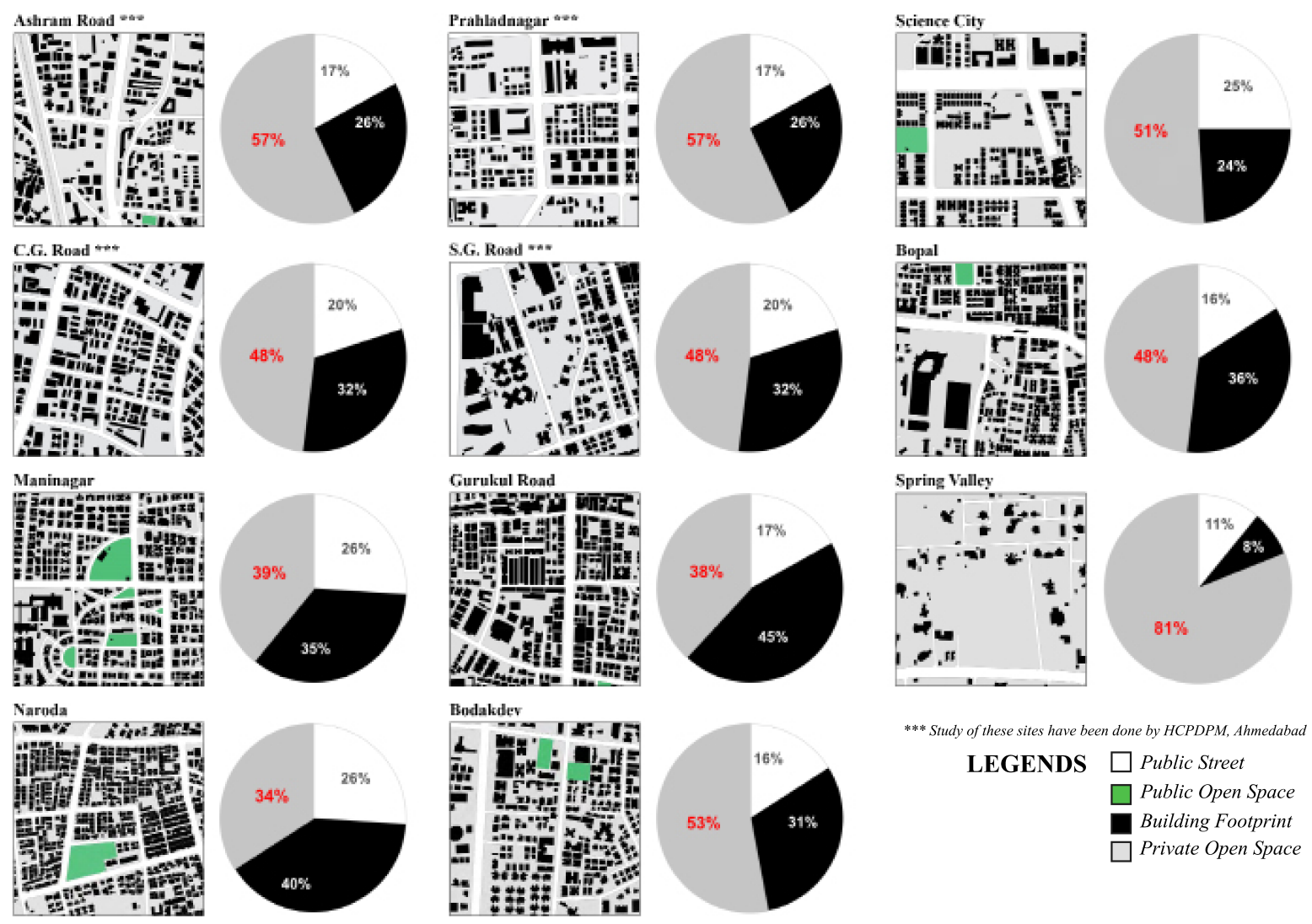

Figure 3. Land Utilization in Indian Cities (Ahmedabad as a case).

(Source: Author)

\subsection{Inference:}

\section{Observational Inference:}

The majority of land area remains under Private Open Space in the areas developed under recent DCRs. For example, more than 50\% of land remains under Private Open Space in the case of Ashram Road, Bodakdev, Prahladnagar, S.G.Road, Science City, Spring Valley. The higher percentage of land is in private open spaces, which are distributed and divided under roadside, side, and rear margins, margins between buildings, thick plantation, common plots covered by parking, internal roads, etc., as per the prevalent DCRs.

This observation leads to the question, "How private open spaces are used in the existing scenario?" 


\subsection{Use of Private Open Space in Indian Context (Ahmedabad as a Case)}

To understand the existing situation of private open space, a primary study has been done on the selected squares. From the study, it can be seen that most of the marginal space are underutilized; some places they have been encroached; Common Plots that are designed for community activities and children to play, are used for parking (Figure. 4).
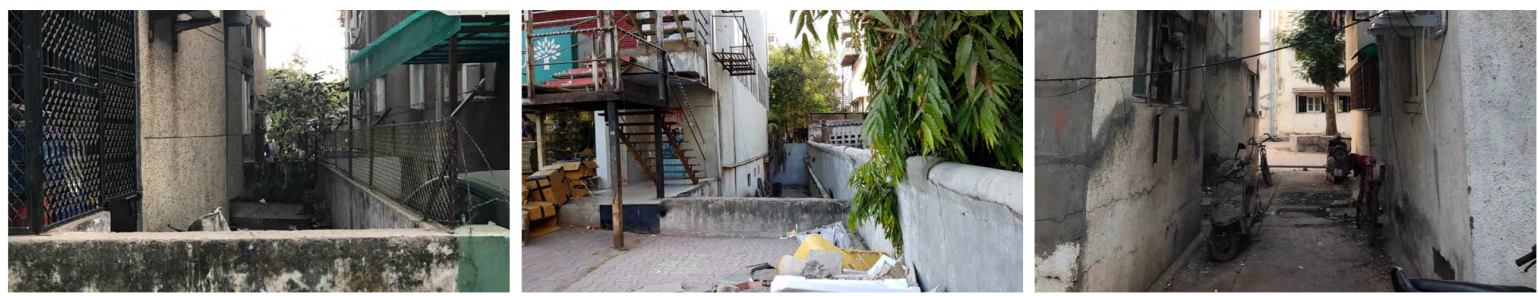

Margin Spaces are Underutilized
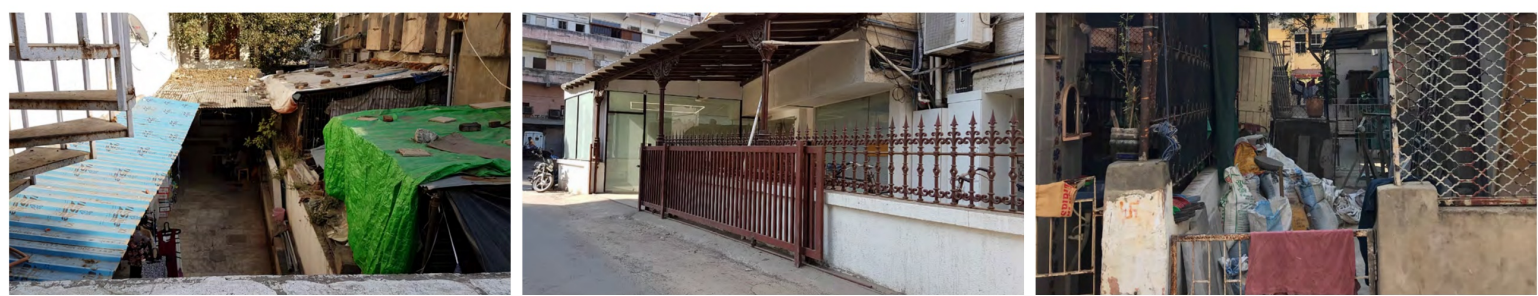

Margin Spaces are Encroached
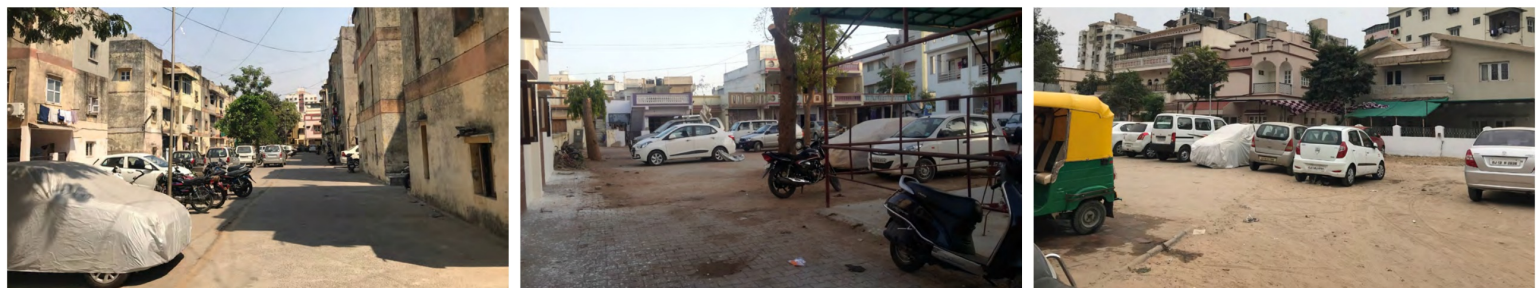

Common Plots which are designed for community activities and children to play, are used for Parking.

Figure 4. Use of Private Open Space in Indian Context (Ahmedabad as a case). (Source: Author).

This leads us to see whether it is happening in other world cities as well? How much land are they (other world cities) using as Private Open Space? How efficiently land utilized there?

\subsection{Land Utilization in Other World Cities:}

In India (Ahmedabad as a case), a higher percentage of the land is in private open space, especially in areas that are developed under recent DCRS - private open spaces are underutilized or encroached, as inferred earlier. But there are a number of cities in the world where there are no such cases, the land for private open spaces are much less in comparison to land in public realm or used for building footprints, and these cities work without 
compromising the basic functionality of circulation - access and Quality of Life. Here are some examples in Figure. 5.

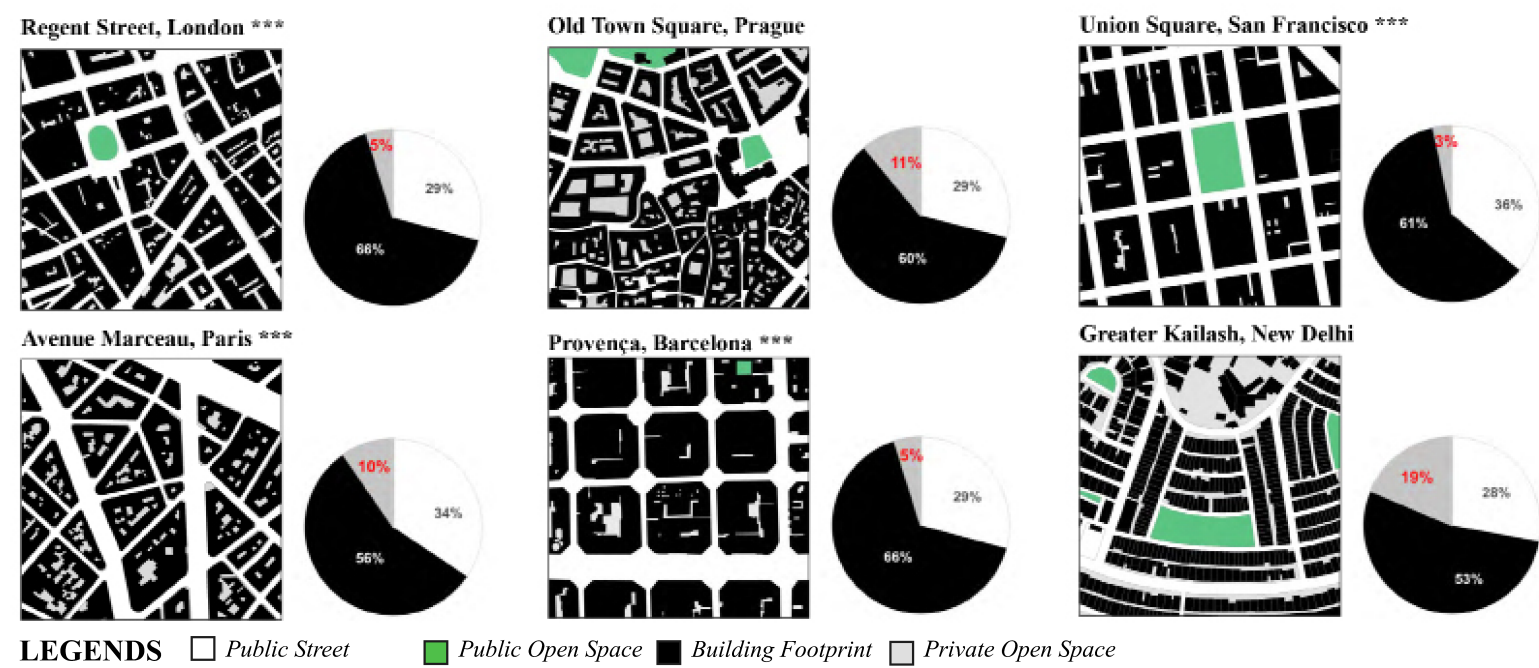

Figure 5. Land Utilization in Other World Cities (Ahmedabad as a case). Source: Author

From the comparison, it is clear that other cities do not require a large amount of private open spaces around the buildings, which clearly indicates that in Indian cities, the land is not efficiently utilized in comparison to other world cities. So, why do people provide so much space around the buildings in Indian cities?

a) Is it out of people's choice? *People - who invest in making the building

Or

b) Are they forced to do so?

To understand, what forces them to provide so much space around the buildings? The study begins with the evaluation of Development Control Regulations, as DCRs controls and regulates the physical growth of towns and cities (Patel et al., 2018).

\section{IMPACT OF DEVELOPMENT REGULATIONS:}

\subsection{Development Control Regulations:}

"As per the D. Thomas, the main aim of the Development Control Regulations is to ensure that land is developed in an organized and reasonable manner in order to create sustainable human settlements that can accommodate a range of land use type to meet the needs of the people who live there." (Thomas et al., 2014). Many experts have mentioned that the urban form is shaped by the enforcement of the development control regulations. To check how DCRs effects land utilization, the study has been done specifically to those regulations which have been listed in the Development of Land (AUDA, 2013; Ahmedabad GDCR - $2021 \mathrm{p}$. g. 86-111) and those are Margins, Common Plots, Thick Plantation, Margin between 
Building, Internal Road and Parking. To study the impact of government regulation on land utilization, there is an immense need to check how it works on the plot level.

\subsection{How do the regulations play out on a plot?}

To check the impact of regulation on the plot, the study has been proceeded by analyzing the approval plans of the building in the city (Ahmedabad as a case), Figure. 6. Three approval plans have been selected on the basis of availability and having different areas, as regulation varies with respect to the plot size.

1. Project 1 - Mixed Use (Area - 881 sq. m.)

2. Project 2 - Housing (Area - 2306 sq. m.)

3. Project 3 - Affordable Housing Project (Area - 10596 sq. m.)

\section{Land Utilization study of Project 2}

Project : Housing (Area $=2306$ sq.m.) R1 Zone

Source of Approval Plan: Groundwork Architecture, Ahmedabad
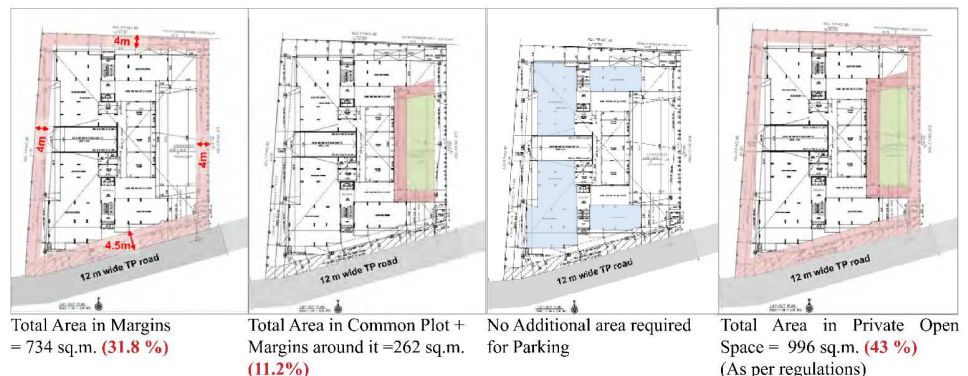

Margins around it $=262$ sq.m. for Parking

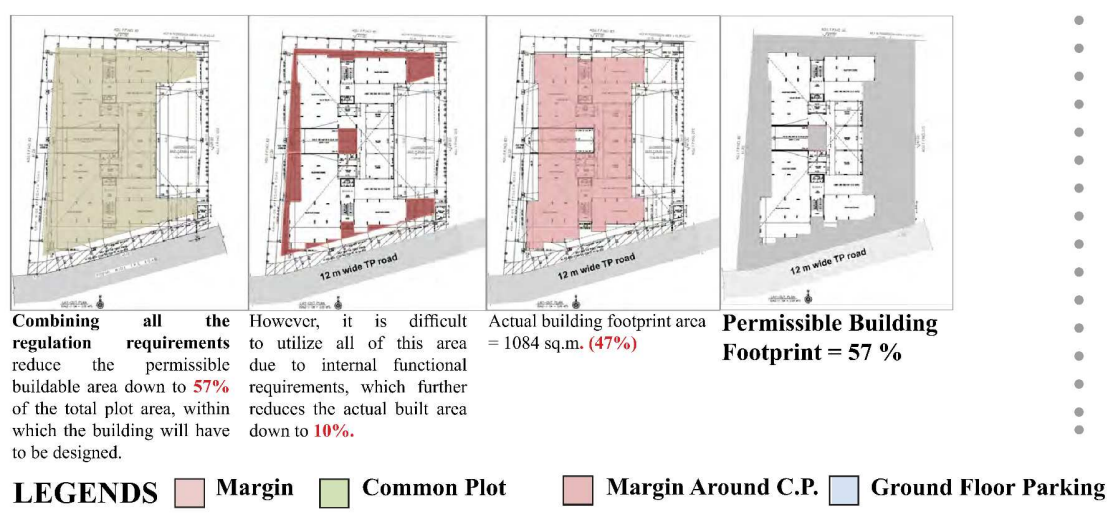

As per the current development regulation, more than 50\% of land is in Private Open Space

Project 2: Housing (Area- 2306 sq.m.)

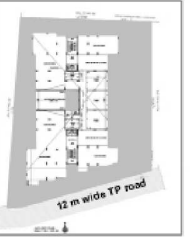

Project 3: Affordable Housing Project (Area- -10
Comparative Analysis of all the three projects
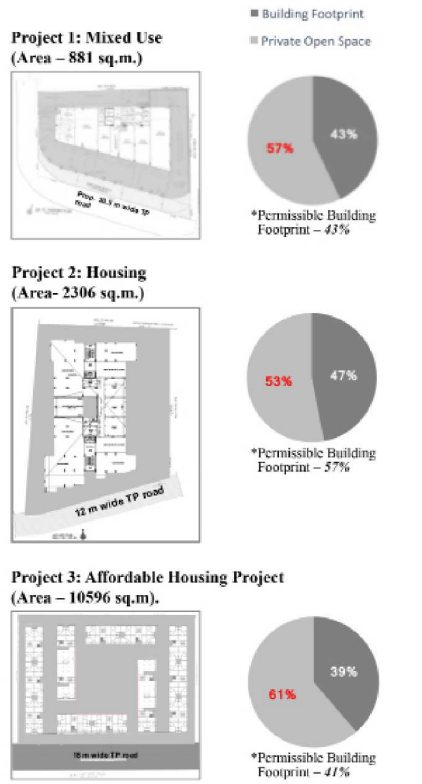

Figure 6. How do the regulations play out on a plot? (Source: Author)

\subsection{Why is so much open space demanded in a Plot, as per the Regulations?}

There are certain underlying assumptions, which are never made explicit or recorded; nor they are based on any empirical studies. But they are always assumed while framing Development Control Regulations. These are:

Assumption 1: Margins are required for fire safety.

Assumption 2: Margins results in addition of green spaces. 
Assumption 3: Margins and ground coverage are must for air and ventilation.

Assumption 4: Margins are required for parking.

Assumption 5: Common places are essential for community gathering spaces and play area.

To check these assumptions really exists in the real world, observational study has been done with respect to the existing scenarios.

\subsubsection{Assumption 1: Margins are required for fire safety.}

Generally, regulation makers (planners or designers) argued that in Indian cities margins are required for fire safety. However, in reality it is impossible for fire safety vehicles to enter margins due to various reasons, Figure. 7(i).
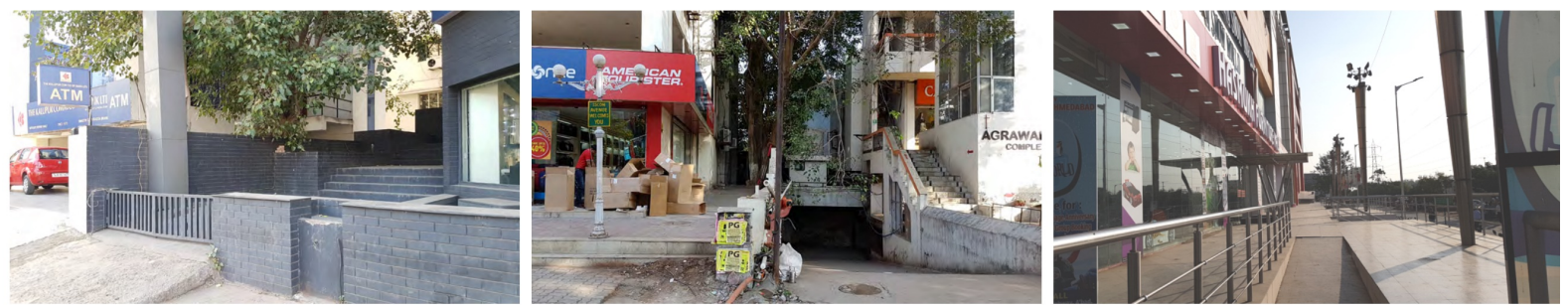

Figure 7. (i) Marginal space used for steps, Vehicular Ramps, Barricading.

(Source: Author)

Contrary to the regulations of Indian Cities, the other world cities do not require any front or side margins and those cases provide much more convenience and direct access to the building in case of fire. As it can be seen in examples, Figure. 7(ii).
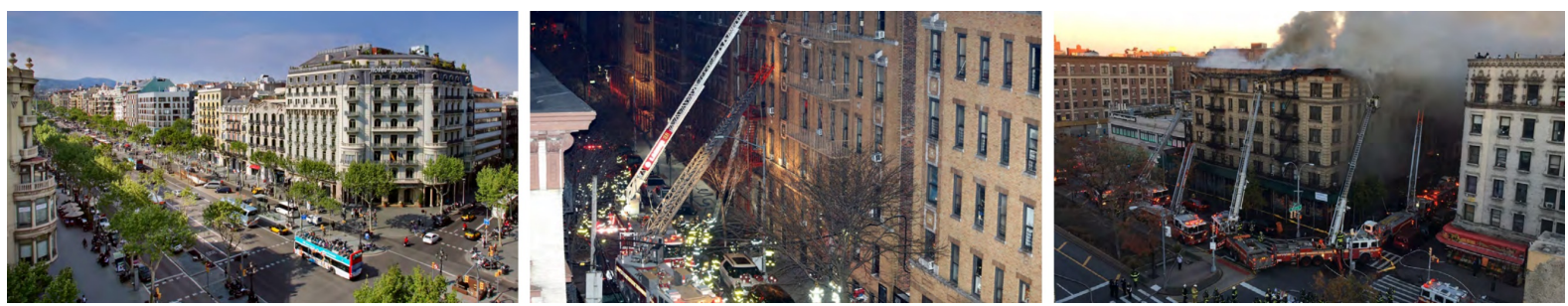

Figure 7. (ii). No front and side margins, but easily accessible by fire safety vehicles.

(Source: Author)

\subsubsection{Assumption 2: Margins result in addition of green spaces.}

Regulation makers (planners or designers) also argued that in Indian cities margins result in addition of green spaces. However, in reality majority of margin space are left vacant and only few results in green space, which can be seen in Figure. $8(\boldsymbol{i})$.
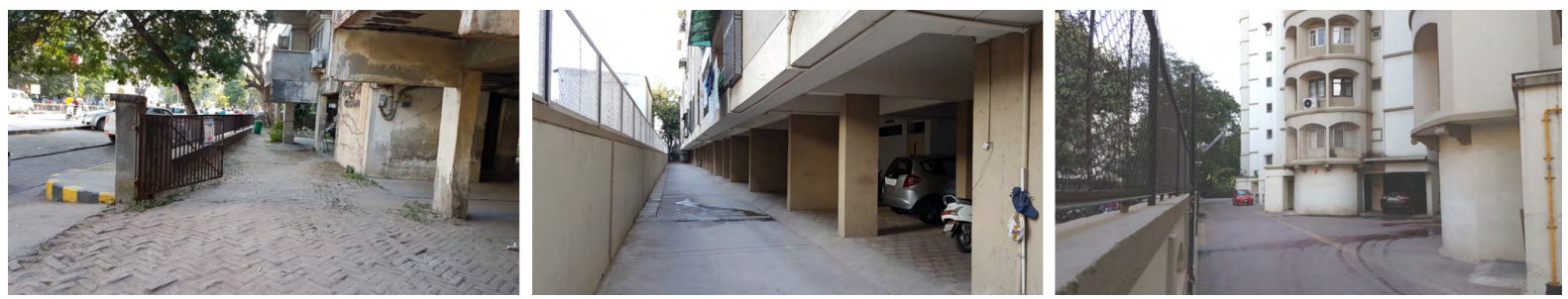

Figure. 8(i). Margins are lef vacant or used as a passage. (Source: Author) 
Contrary to this, if these margin spaces are combined into one single common space, it would result in larger, easily accessible and more usable green spaces, Figure. 8(ii).
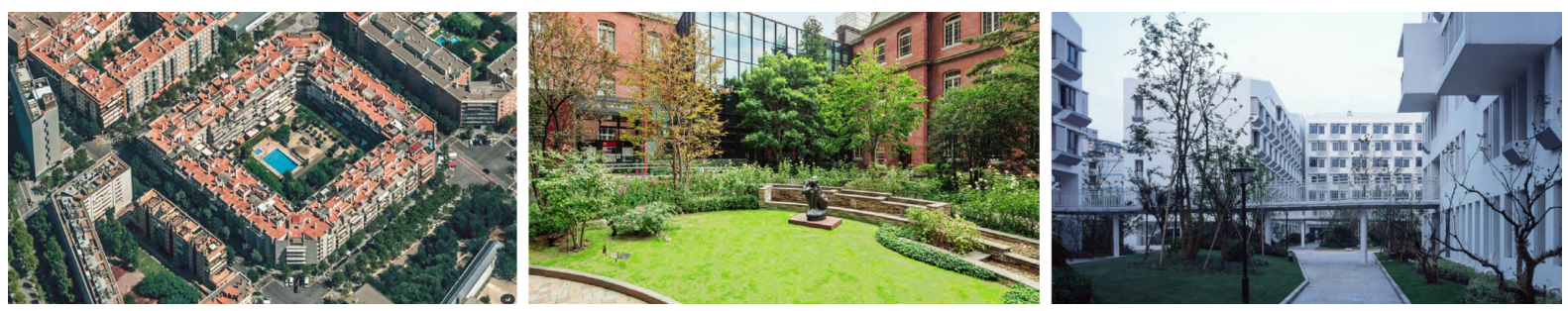

Figure 8. (ii). Courtyard as a Public Spaces and Garden.

(Source: Author)

\subsubsection{Assumption 3: Margins and ground coverage are must for light and ventilation.}

Regulation makers (planners or designers) argued that in Indian cities margins and ground coverage are must for light and ventilation. However, cities all over the world, including India, have been built without requiring margins or restricting ground coverage and they have no problem of light and ventilation, Figure. 9.
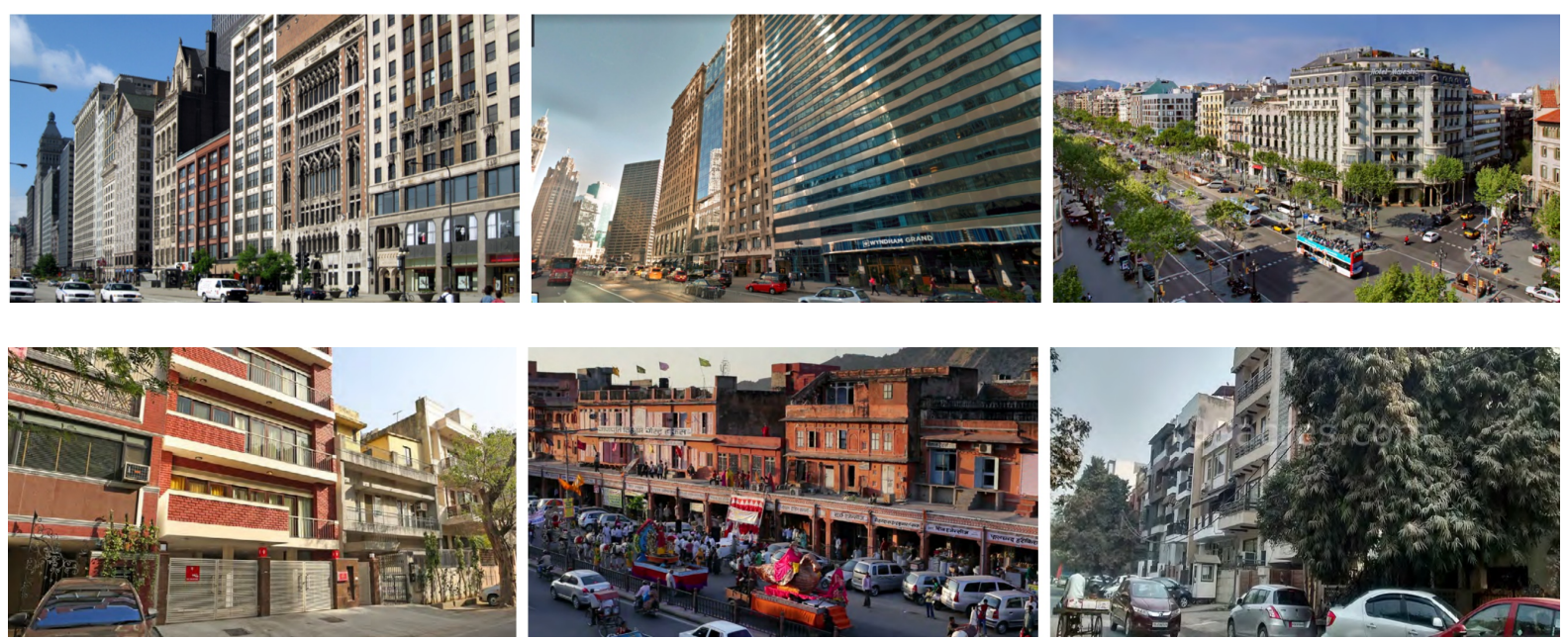

Figure 9. No Front and Side Margins.

(Source: Author)

\subsubsection{Assumption 4: Margins are required for parking}

Regulation makers (planners or designers) argued that in Indian cities margins are required for parking. However, in existing scenario space remains vacant, inaccessible for vehicles, and underutilized in most of the cases and roads are encroached by vehicle, Figure. 10. 

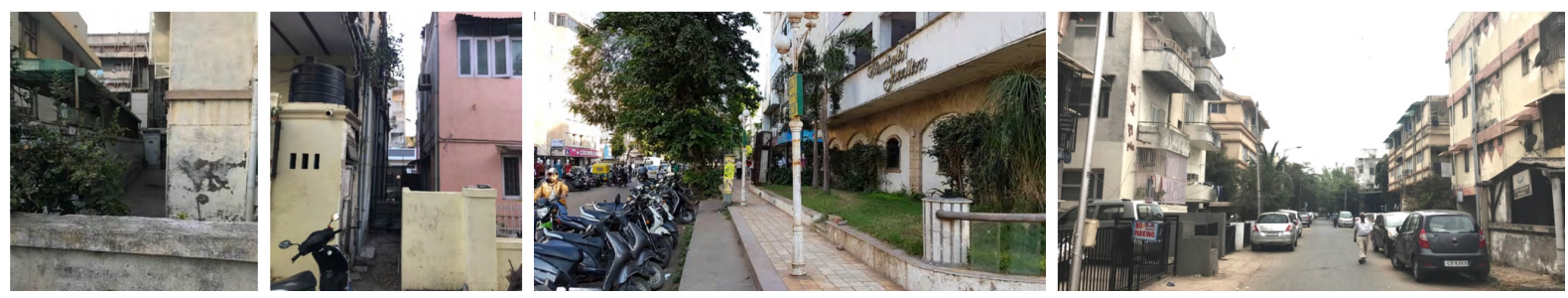

Figure 10. Marginal Spaces are vacant or used for other purpose and roads are used for parking. (Source: Author)

\subsubsection{Assumption 5: Common plots are required for community activities and children to play.}

Regulation makers also argued that common plots are required for community activities and children to play. But DCRs allows $50 \%$ of the common plot can be used as a Parking Space in case of Residential Use. In result of it, most of the common plot area used as a parking space in existing scenario, which can be seen through given examples, Figure. 11.
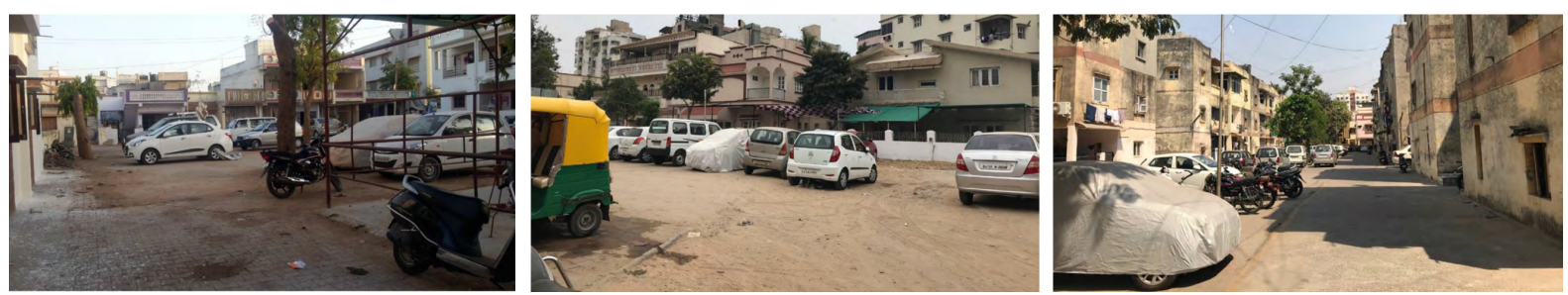

Figure 11. Common Plots are used for parking. (Source: Author)

\section{Inference -}

The observations reveal that these underlying assumptions are incorrect. It is also clear that the Development Control Regulations may not serve the purpose for which they are framed. So how should they be framed/improved?

\section{RETHINKING REGULATIONS:}

This research has been able to bring out that Development Control Regulations play an important role in shaping a city and in land utilization. From the above discussion, it is clear that the existing DCRs in India (Ahmedabad as a case) are forcing people to make more Private Open Space in their building units and there is no proper justification for these regulations. The creation of these regulations is much more depends on the certain underlying assumption, which is also been proved by the observational study- that those are incorrect, there are other world cities functioning without the assumed requirement.

Therefore, there is an urgent need to rethink the Development Control Regulations, as the urban land is limited and population in the cities is increasing in high pace which will lead to the horizontal expansion of the city. To accommodate future requirement, land has to be efficiently used. 
From the above learnings, some recommendation in the DCRs has been suggested in this research, which will impact on the urban land by increasing land in the Permissible Building Footprint or in the Public Realm. These are:

1. Roadside Margins are not Required.

2. No Common Plot Required in Commercial Development.

3. Common Plot Required for the Residential Development, but doesn't have to be at Ground Level.

4. No compound walls between plots to allow shared

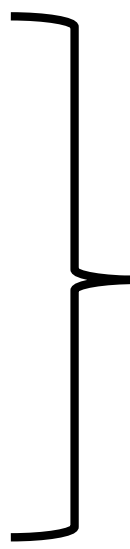

Increasing

Permissible

Building

Footprint Area parking between plots.

5. Taking Roadside margins in Public Domain. (Option other than regulation 1Roadside Margins are not required)

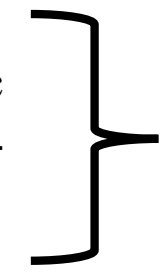

Increasing Public Realm Area

\subsection{Increasing Permissible Building Footprint Area}

\subsubsection{Roadside Margin are not Required.}

Roadside margins are generally useable for places where - street has to be expanded in the future or to provide privacy to people residing in the building from the street traffic. Street expansion depends on the city requirement and the privacy depends on the people who will reside or use the building. To improve the land utilization, if we remove the roadside margin compulsion and state that the Roadside Margin are not Required (if there is no need of street expansion), then it will provide flexibility to people to build as per their need whether it can be maximizing the use of land or their privacy, Figure. 12(i). In most of the cases people will tend to make built-to-line buildings, as land is limited, which will not only improve the efficiency of land utilization but also give definition to the street and enhances the walking experience. In case of mixed use or commercial edge, Built-to-line (No Roadside Margin) can be required, which will provide better access, improve shopping experience and convenience for loading and unloading in shops. 


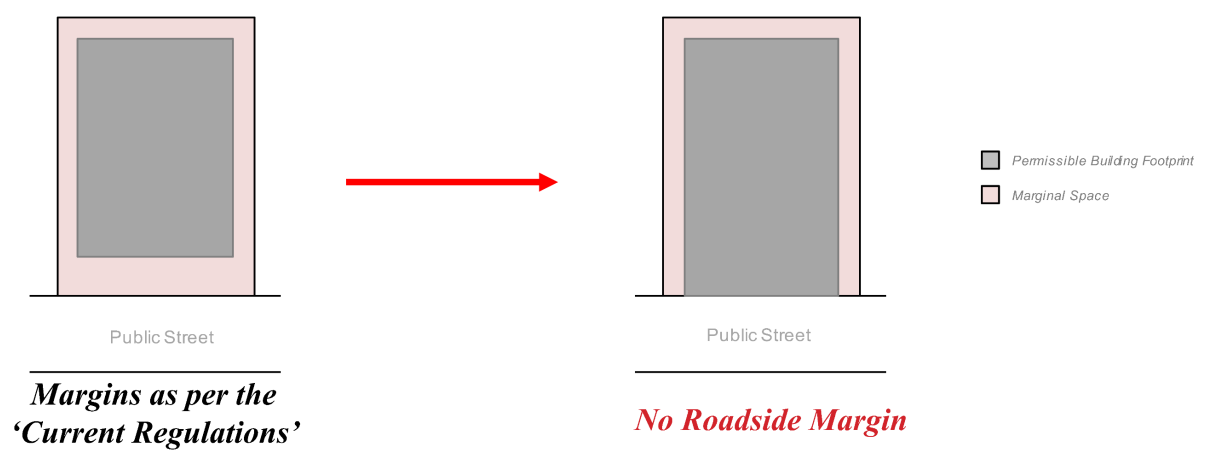

Figure 12. (i). Graphical Representation of Regulation. (Source: Author)

\subsubsection{No Common Plot Required in Commercial Development}

Common plots are generally designed for community gathering and play area for children. In case of commercial building unit, common plot is not needed for both the scenarios, as for any kind of interaction there is maximum possibility of people to use public street and there is no such requirement for children's play area. In existing scenario, common plot in commercial area are generally occupied for parking, because DCRs (Ahmedabad) has a regulation, according to which complete area of common plot can be used as parking space (Byahut et al., 2020). As Common plot of commercial land only used for parking, if 'No Common Plot required in Commercial Development' regulation can be applied then the parking requirement can be managed in the basement or in the Public Street and land will be used in permissible building footprint, Figure. 12(ii).

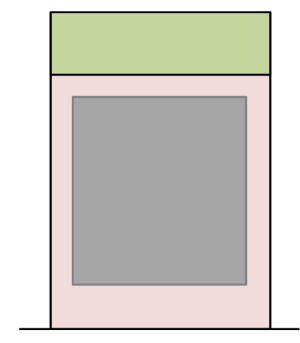

Public Street

Margins and Common plot

as per the Current Regulation

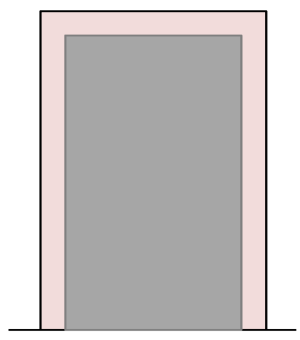

Public Street

No Common Plot requirement

from Commercial Development $\square$ Permissible Buldang Footprint

$\square$ Marginal Space

Figure 12. (ii). Graphical Representation of Regulation. (Source: Author)

\subsubsection{Common Plot Required for the Residential Development but doesn't have to be at Ground Level}

Common plot for residential is essential for community gathering and children to play. But is it necessary to keep common plot on ground floor? As in other cities like Mumbai, Malaysia, etc. there are many building units which have common plots above the ground level, Figure. 12(iii). 

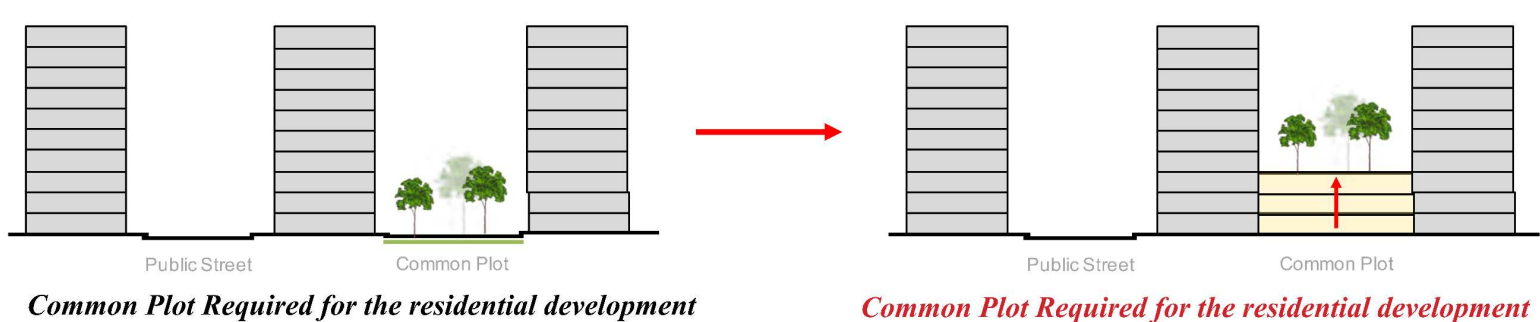

Common Plot Required for the residential development but doesn't have to be at Ground Level

Figure 12. (iii). Graphical Representation of Regulation. (Source: Author)

\subsubsection{Compound Walls - No compound walls between plots to allow shared parking between plots.}

In Indian Cities (Ahmedabad as a case), there is a high demand of the parking, it can be seen through the existing condition of common plots as they are designed for gathering space but used as a parking space. There is a need of a regulation through which shared parking can happen. For that compound wall between adjacent plots can be removed to allow shared parking, Figure. 12(iv).
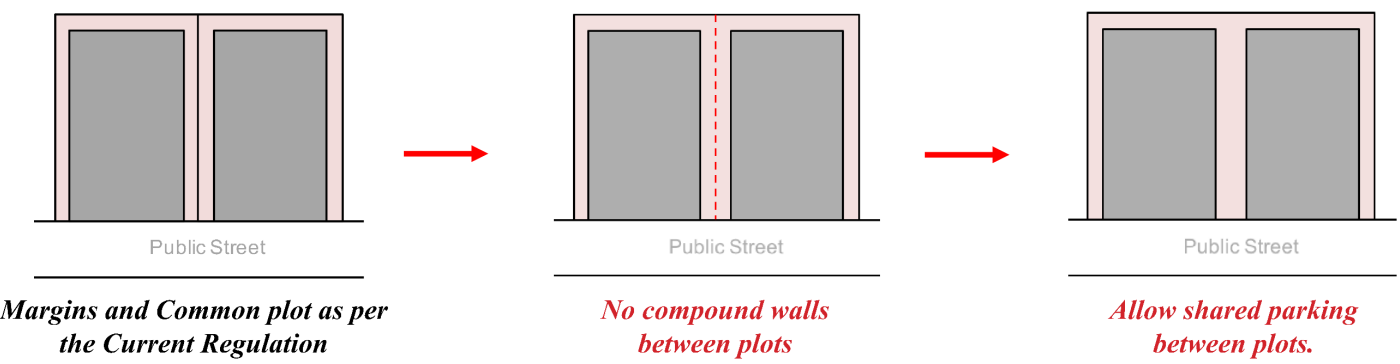

Figure 12. (iv). Graphical Representation of Regulation. (Source: Author)

\subsection{Increasing Public Realm Area:}

\subsubsection{Taking Roadside margins in Public Domain. (Option other than regulation.1- Roadside Margins are not a Required).}

In future, urban population will increase as per (TERI, 2016) document. There will be requirement of more public space, without compromising the building footprint area. To achieve that if the existing roadside margin has been taken as a part of public realm and following above recommended regulations of common plot - no common plot for commercial and common plot required for residential but doesn't have to be on ground floor (TERI, 2016). Then the public realm area will increase but permissible building footprint area will remain same, Figure. 12(v).

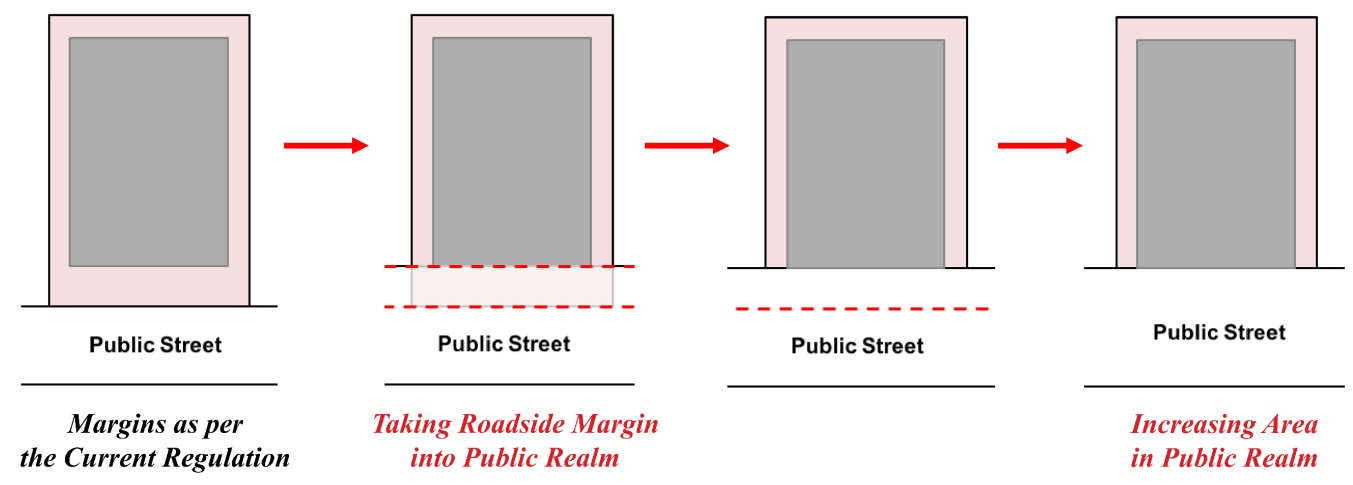

Figure 12. (v). Graphical Representation of Regulation. (Source: Author) 


\subsection{Conclusion}

The quantitative and qualitative understanding of selected squares in Ahmedabad city brings out that the higher percentage of urban land is in Private Open Space which is underutilized in existing condition, while other world cities do not require such a large chunk of land in private open space but still they utilize their urban land efficiently, without compromising the basic functionality of circulation and access in the city. In the course of researching, it also became clear that the most pressing unresolved issue of land utilization are so much to do with the Development Control Regulations of the city. As per the current regulation more than $50 \%$ of land are forced to go in Private Open Space. It highlights the crucial role of DCRs on the efficiency of urban land utilization, it also highlights how regulation makers (planners and designers) are following the underlying assumption while framing regulation without analyzing it with the existing scenarios.

In future, to use urban land efficiently, regulations need to be rethought without compromising with the circulation and accessibility in the city. Once Jan Gehl has said, "Something happens because something happens because somethings happens". Following his quote, we really need to improve our development control regulation to get efficient use of urban land for future generations. As improved regulation would lead to efficient Land Utilization.

\section{ACKNOWLEDGEMENT -}

The paper is intended as a reference work for Urban Designers and Urban Planners - to understand the existing land utilization of Indian City (Ahmedabad as a case) and how it can be improved. As an author of this paper, I would like to express my gratitude to Prof. Jignesh Mehta (Adjunct Associate Professor, MUP, CEPT University, Ahmedabad) for guiding throughout the research process with great patience and understanding. I am grateful to all those people, who has helped while documenting the sites, and firms - HCPDPM, Groundwork Architecture for providing documents which have been important part of the study. Last but not the least, special thanks to my parents, brother and my friends for their continuous moral support, without which this paper would not be possible.

\section{FUNDING:}

This research did not receive any specific grant from funding agencies in the public, commercial, or not-for-profit sectors.

\section{CONFLICT OF INTEREST:}

The author declares that there is no conflict of interest regarding the publication of this manuscript.

\section{REFERENCES:}

Adhvaryu, B. (2011). The ahmedabad urban development plan-making process: A critical review. In Planning Practice and Research (Vol. 26, Issue 2, pp. 229-250). Routledge . https://doi.org/10.1080/02697459.2011.560463

Anguluri, R., \& Narayanan, P. (2017). Role of green space in urban planning: Outlook towards smart cities. Urban Forestry and Urban Greening, 25, 58-65. 
https://doi.org/10.1016/j.ufug.2017.04.007

AUDA. (2013). Revised Development Plan 2021 | AUDA. Auda Dp 2021. http://www.auda.org.in/RDP/

Bertaud, A. (2010). LAND MARKETS, GOVERNMENT INTERVENTIONS, AND HOUSING AFFORDABILITY. www.brookings.edu/global

Bertaud, A., Bertaud, M.-A., \& Wright, J. O. (1988). Efficiency in Land Use and Infrastructure Design: An Application of the Bertaud Model. World Bank Policy Planning and Research Staff, 17, 1-100.

Byahut, S., Patel, B., \& Mehta, J. (2020). Emergence of sub-optimal land utilization patterns in Indian cities. Journal of Urban Design, 25(6), 758-777. https://doi.org/10.1080/13574809.2020.1752646

Patel, B., Byahut, S., \& Bhatha, B. (2018). Building regulations are a barrier to affordable housing in Indian cities: the case of Ahmedabad. Journal of Housing and the Built Environment, 33(1), 175-195. https://doi.org/10.1007/s10901-017-9552-7

Rosanna, M. M., \& Chapin, F. S. (1957). Urban Land Use Planning. The American Catholic Sociological Review, 18(3), 268. https://doi.org/10.2307/3708728

TERI. (2016). Urban Resilience - Urbanisation. https://www.teriin.org/resilientcities/urbanisation.php

Thomas, B. D., Use, L., Consultant, P., \& Authority, D. C. (2014). The Importance of Development Plans / Land Use Policy for. 2-6.

http://www.oas.org/pgdm/document/bitc/papers/dthomas.html 
Figures

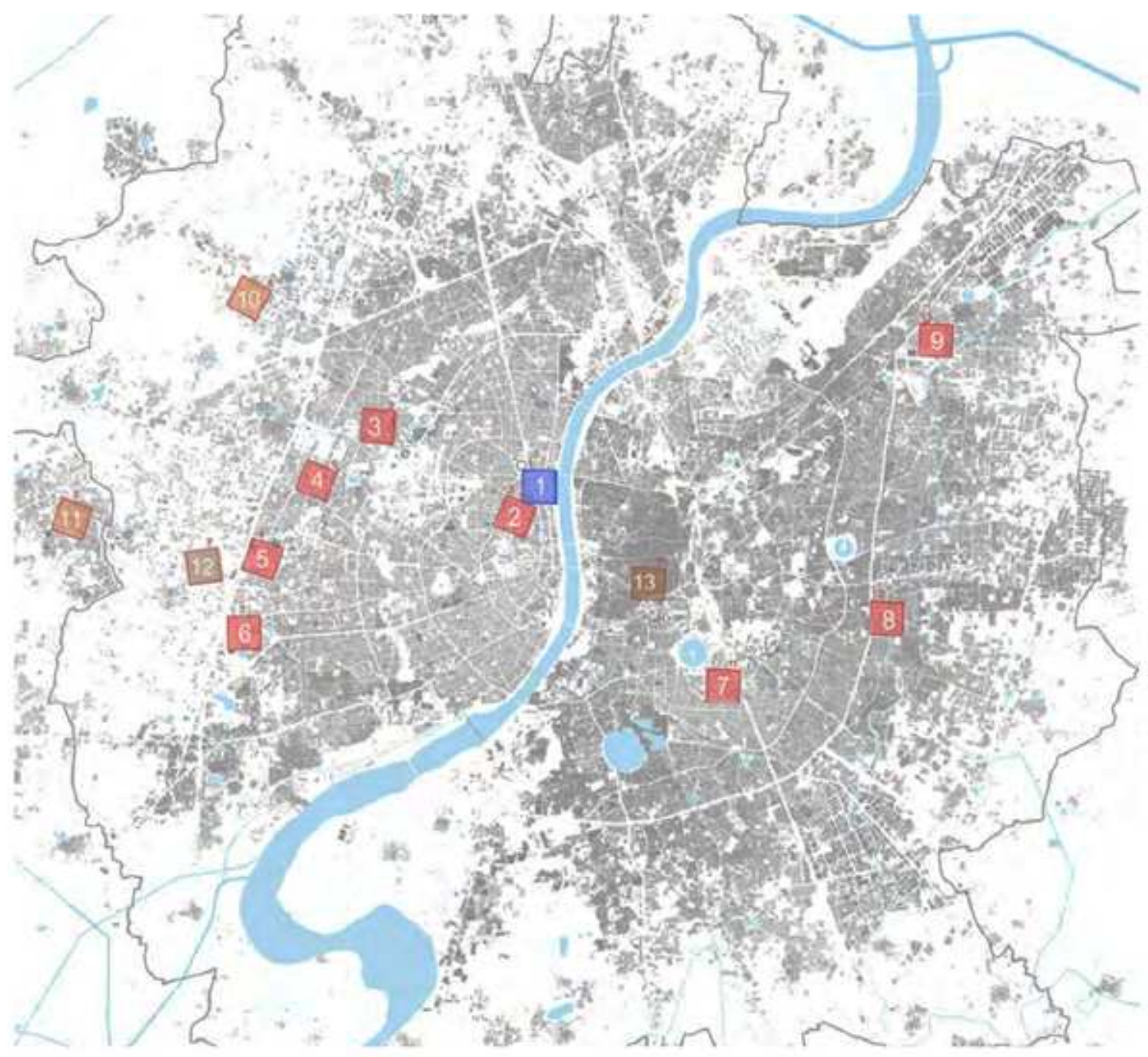

Thirteen sites are:

Central Business District (CBD)

1. Ashram Road***

R1 Zone

2. C.G. Road****

3. Gurukul Road

4. Bodakdev

5. S.G. Road***

6. Prahladnagar***

7. Maninagar

8. Rameshwar Park

9. Naroda
R2 Zone
10. Science City
11. Bopal

R3 Zone

12. Spring Valley

Core City

13. Khadia

*** Study of these sites

have been done

by HCPDPM, Ahmedabad

\section{Figure 1}

Selected Areas across the Ahmedabad City for the Land Utilization Study. (Source of the Ahmedabad Map - HCP, Ahmedabad) 


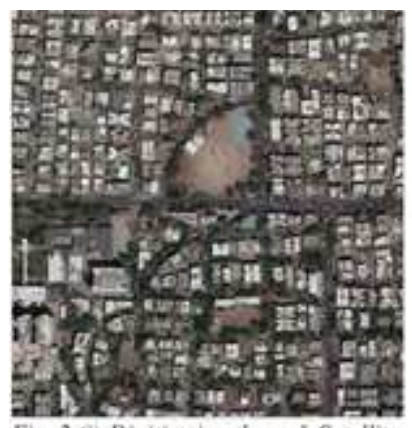

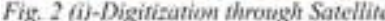
Image (Sotures: Authari)

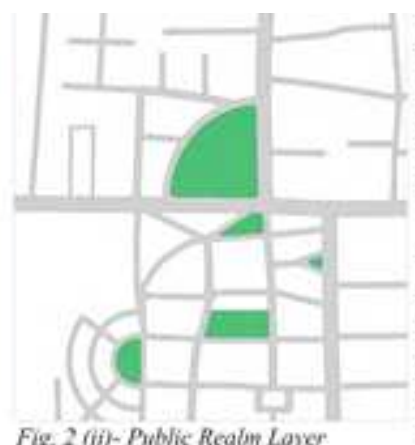

Fig. 2 (ii)-Public Realm Layer

(Sounce: Anthar)

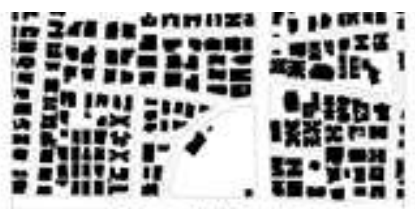

III

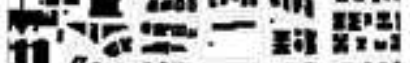

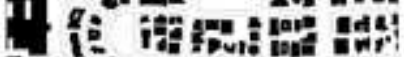

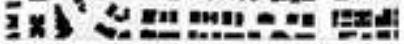
Fig 2 fiil-Building Footprint lojer.

(Smance: Author)

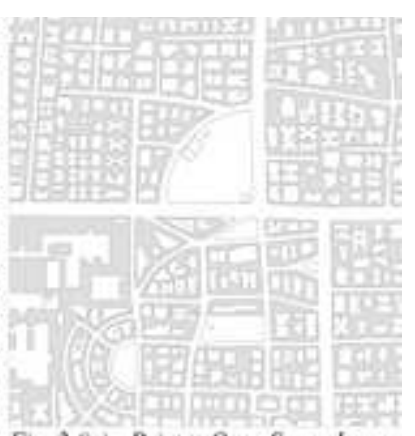

Fig. 2 fiv) - Privute Open Space Laver (Source: futhor)

LEGENDS $\square$ Public Sired

Prublic Open Space

Building Footprint

$\square$ Private Open Space

Figure 2

Layers of the Sample Square (i) Satellite Image, (ii) Public Realm, (iii) Building Footprint, (iv) Private Open Space. (Source: Author)
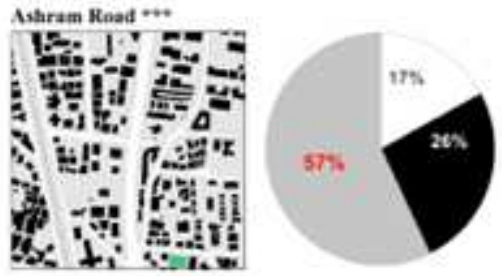

C.6. Rnad on.
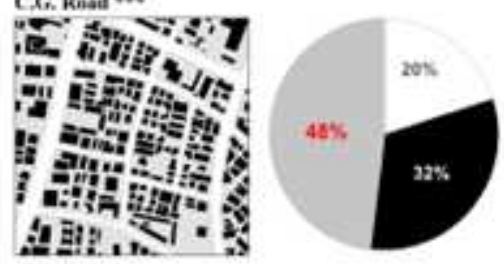

Maninagar
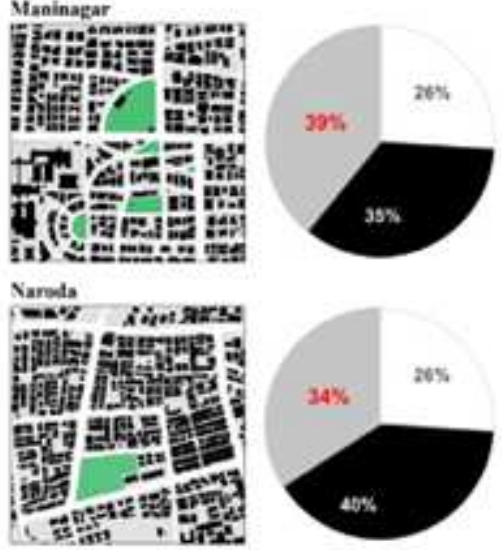

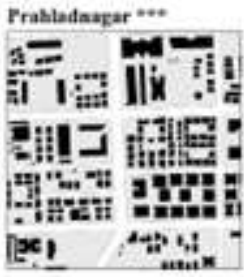

S.G. Read w.

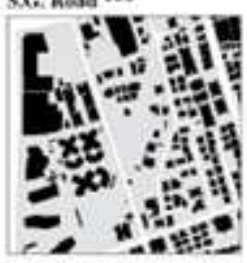

Ginnkisl Road
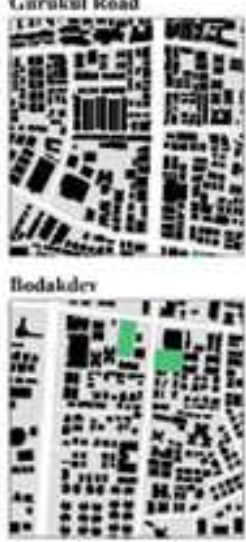
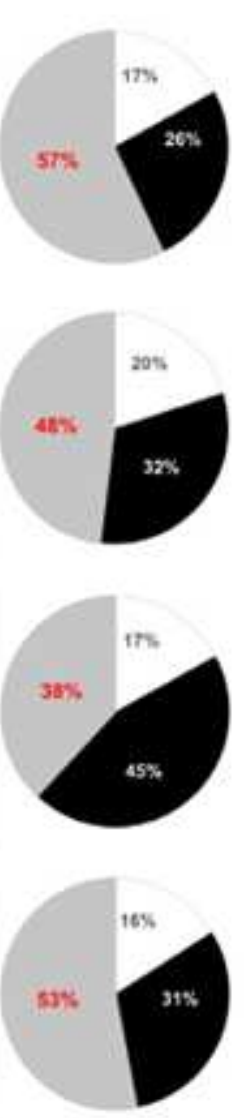
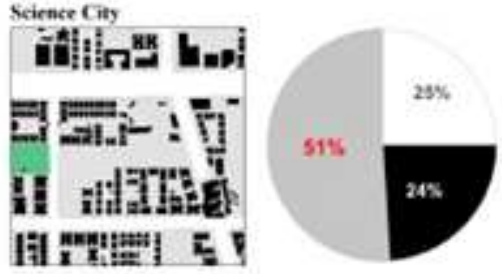

Bopal
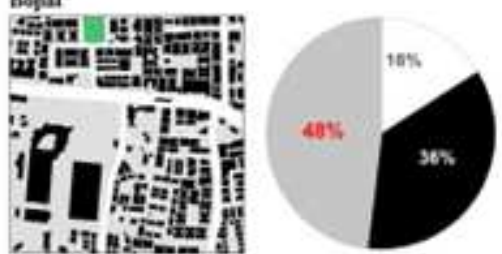

Spring Valley
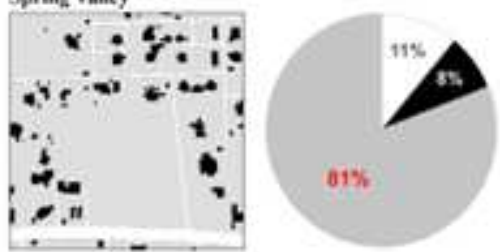

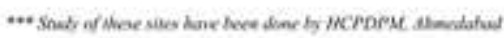

LEGENDS $\square$ Public Strevet

$\square$ Public Open Space

Building Footprint

$\square$ Private Opea Space

Figure 3

Land Utilization in Indian Cities (Ahmedabad as a case). (Source: Author) 

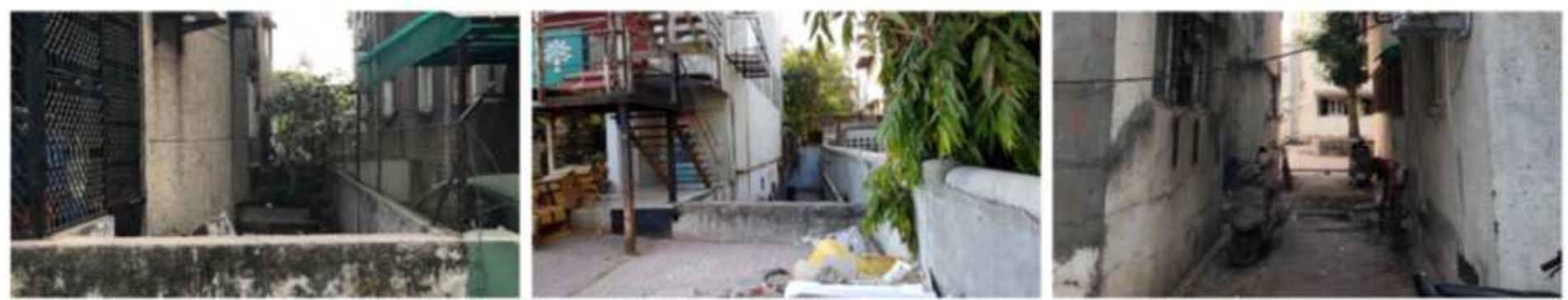

Margin Spaces are Underutilized
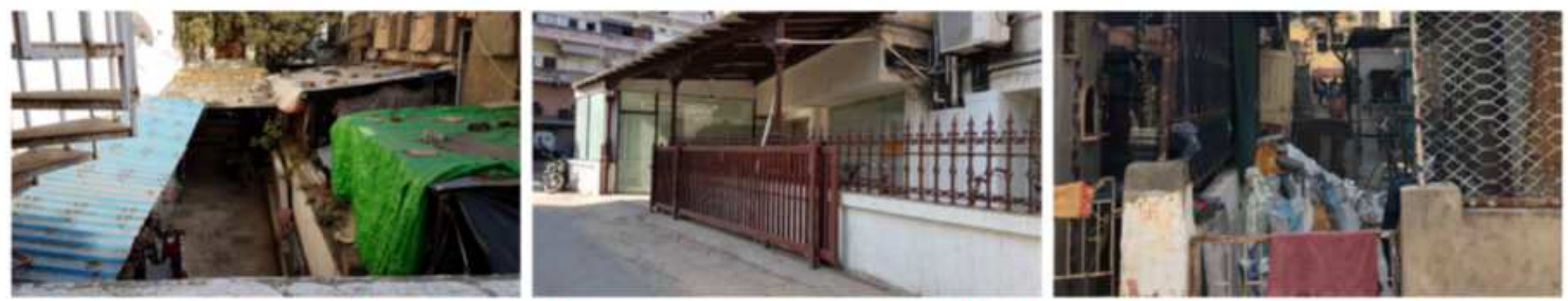

Margin Spaces are Encroached
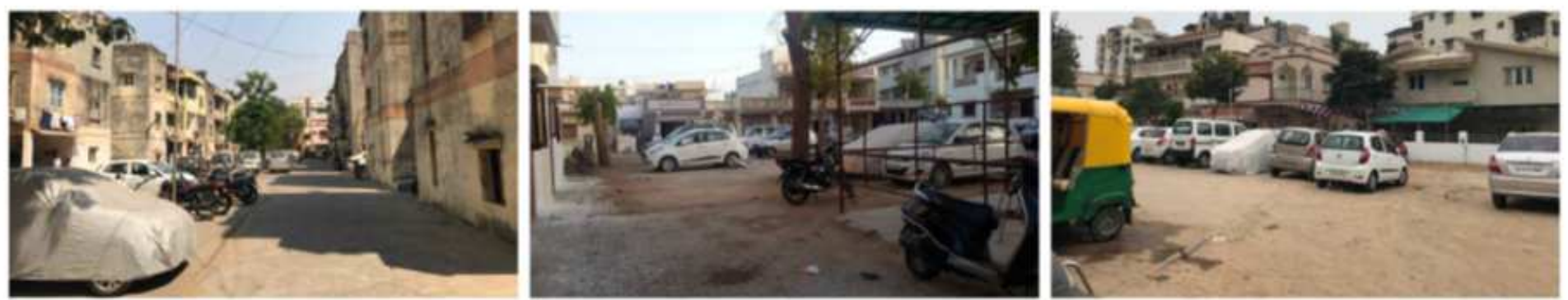

Common Plots which are designed for community activities and children to play, are used for Parking.

Figure 4

Use of Private Open Space in Indian Context (Ahmedabad as a case). (Source: Author).
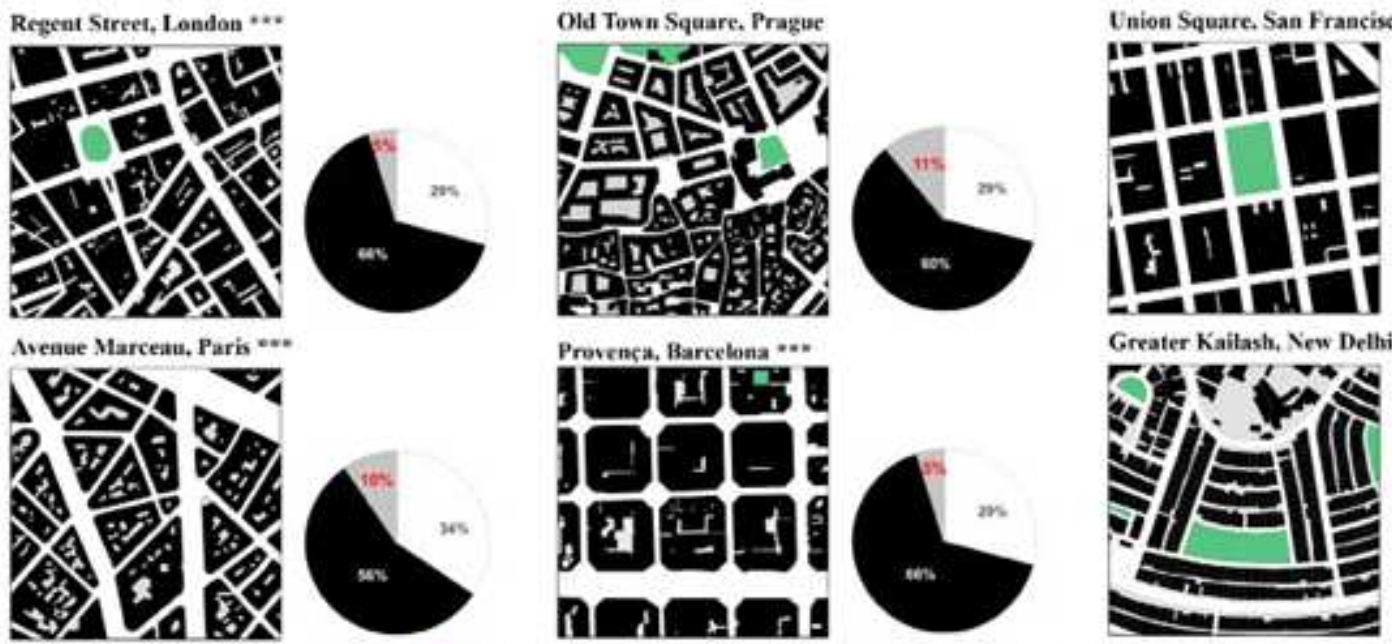

Greater Kailash, New Delhi

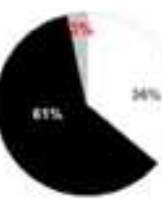

LEGENDS $\square$ Public Street $\square$ Prablic Open Space $\square$ Building Fowprint $\square$ Primate Open Space

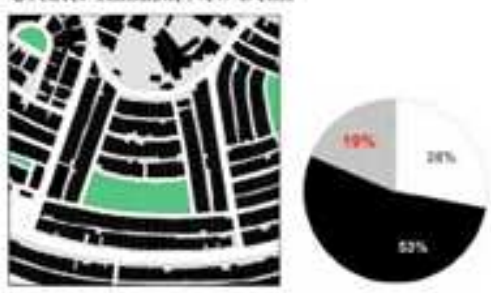

Figure 5 
Land Utilization in Other World Cities (Ahmedabad as a case). Source: Author

\section{Land Utilization study of Project 2}

Project : Housing (Area $=2306$ sq.m.) R1 Zone

Source of Approval Plan: Groundwork Architecture, Ahmedabad
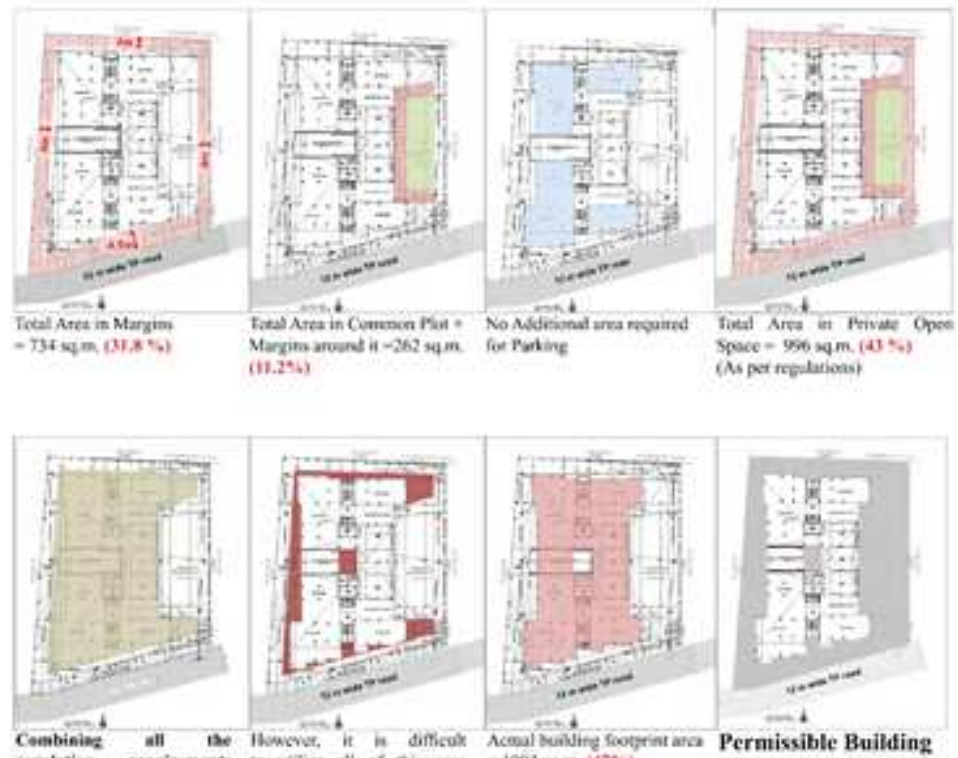

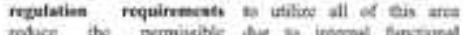

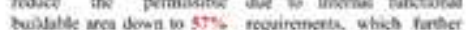

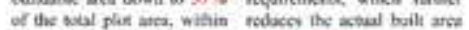

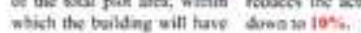

labe devigned.

LEGENDS $\square$ Margin $\square$ Commen Plet $\square$ Margie Aroend C.P. $\square$ Ground Floor Parking
Comparative Analysis

of all the three projects

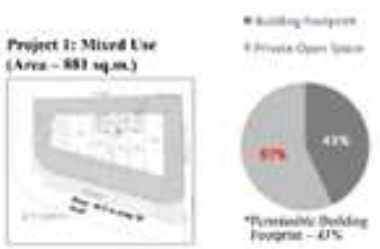

Projes 2: Alaving
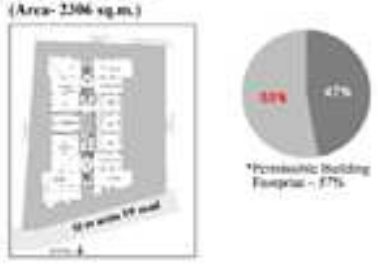

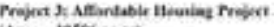

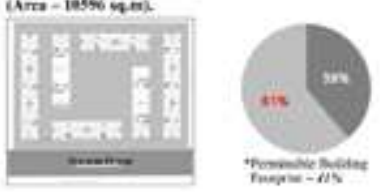

As per the current development regulation, more than $50 \%$ of land is in Private Open Space

\section{Figure 6}

How do the regulations play out on a plot? (Source: Author)
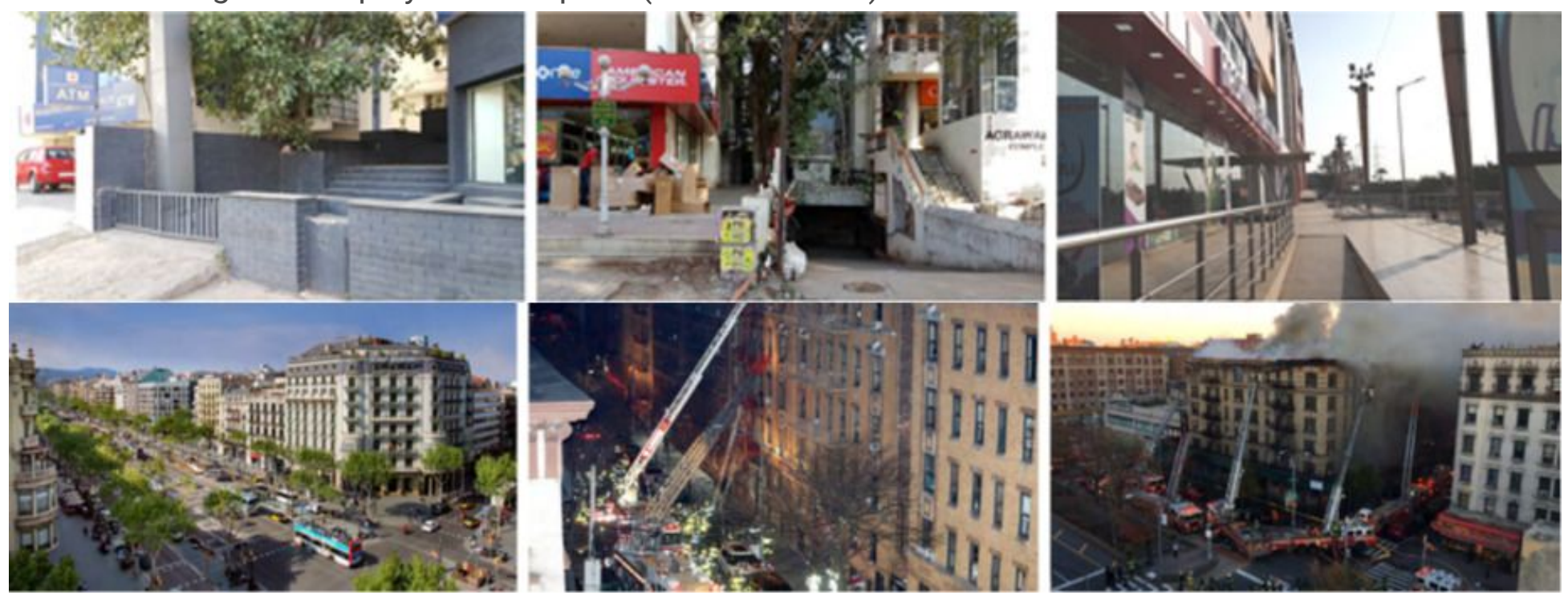

\section{Figure 7}

Top row (i) Marginal space used for steps, Vehicular Ramps, Barricading. (Source: Author) Bottom row (ii). No front and side margins, but easily accessible by fire safety vehicles. (Source: Author) 

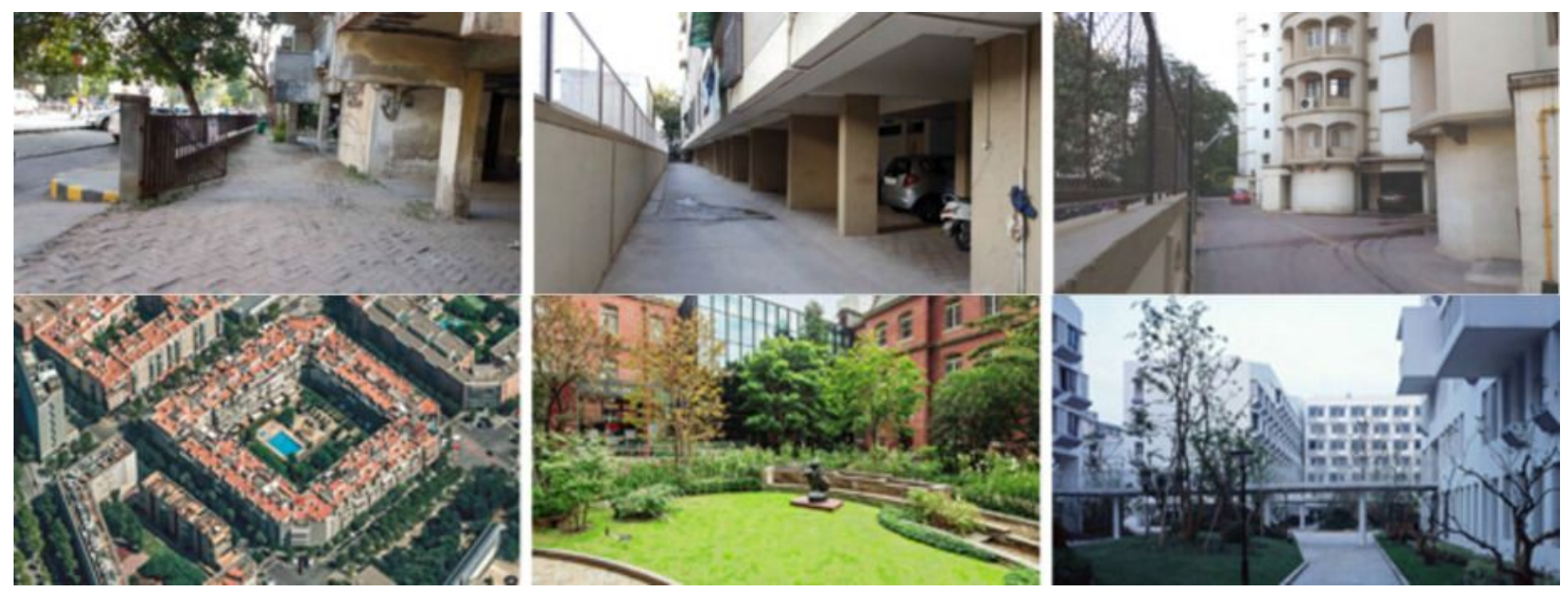

Figure 8

Top row (i). Margins are lef vacant or used as a passage. (Source: Author) Bottom row (ii). Courtyard as a Public Spaces and Garden. (Source: Author)
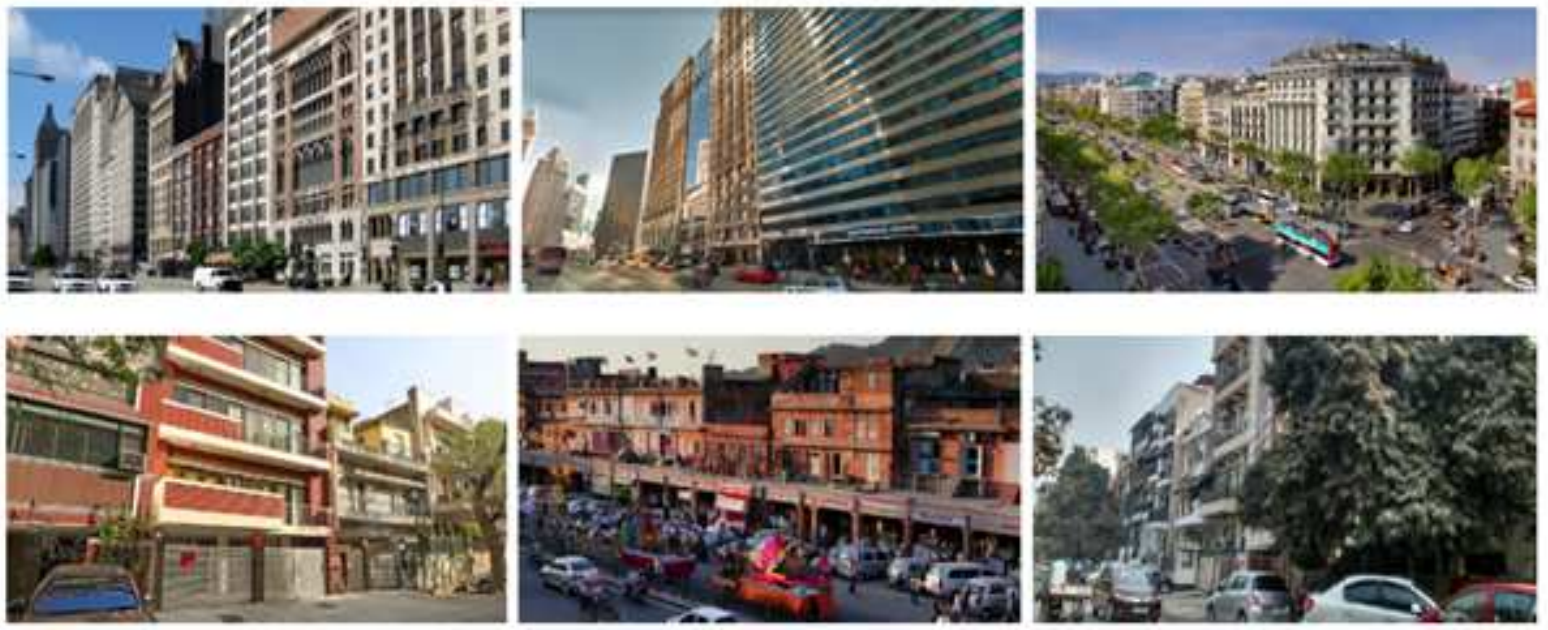

Figure 9

No Front and Side Margins. (Source: Author)
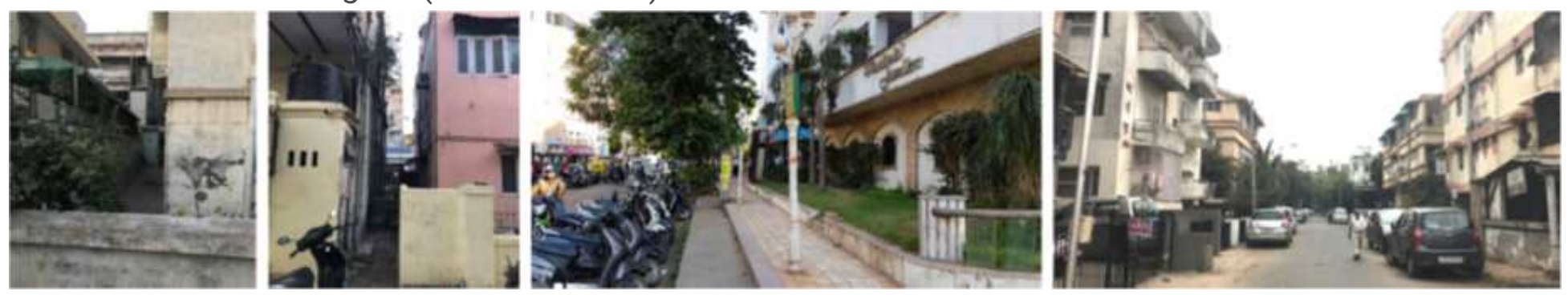

Figure 10

Marginal Spaces are vacant or used for other purpose and roads are used for parking. (Source: Author) 

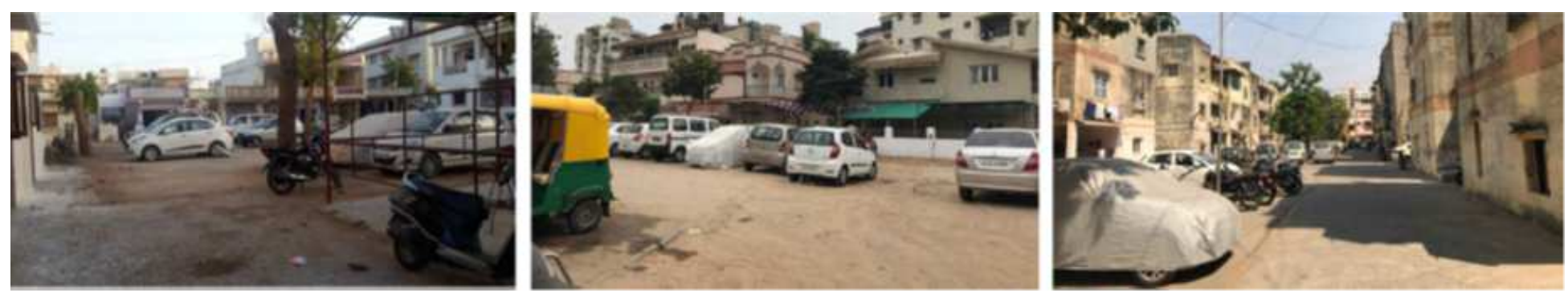

Figure 11

Common Plots are used for parking. (Source: Author) 


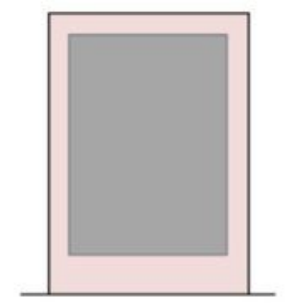

Public Street

\section{$\overline{\text { Margins as per the }}$} 'Current Regulations'

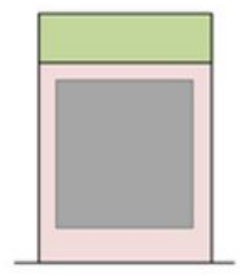

Public Stmet

\begin{abstract}
Margins and Common plot
\end{abstract} as per the Current Regulation

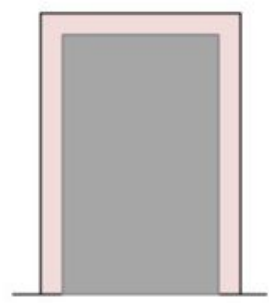

Public Street

No Roadside Margin

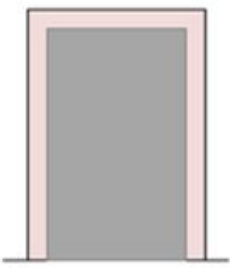

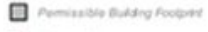

$\square$

Puble Street

No Common Plot requirement

from Commercial Development

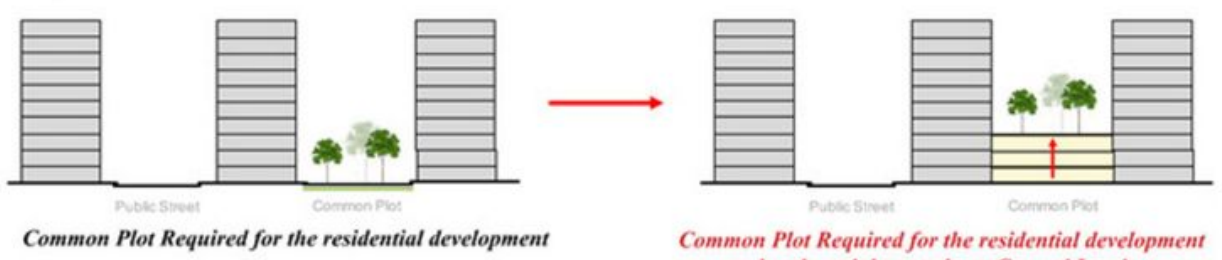
but doesn't have to be at Ground Level

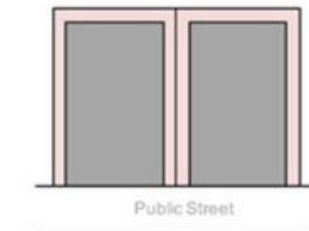

Margins and Common plot as per the Current Regulation
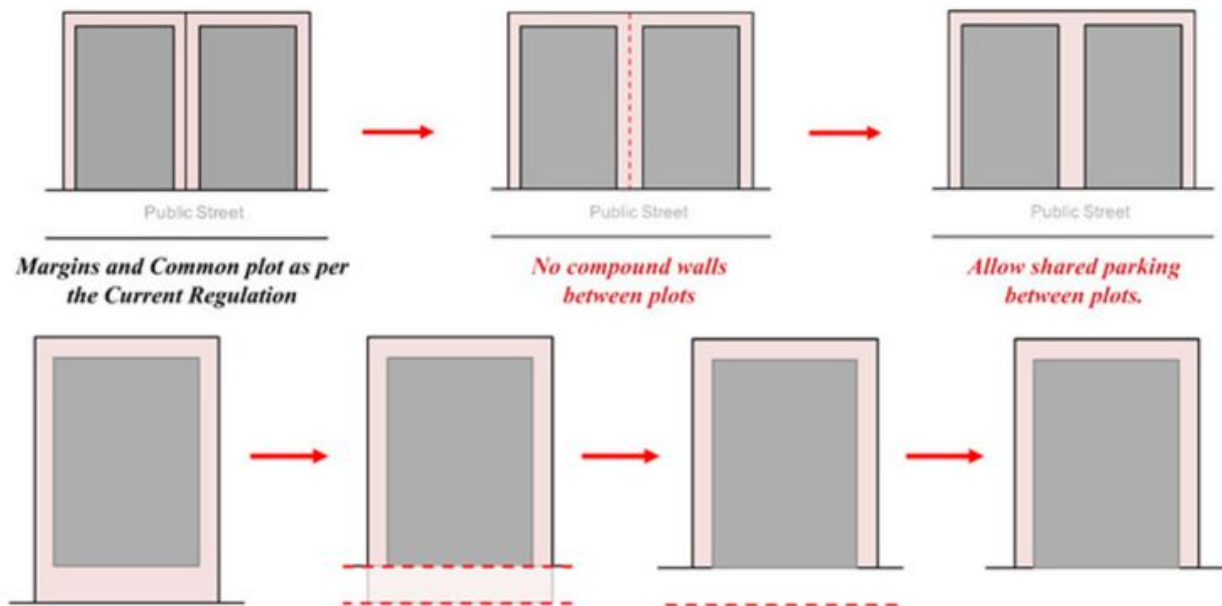

Public Street

Margins as pe the Current Regulation

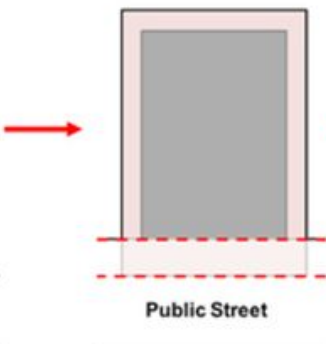

Taking Roadside Margin into Public Realm
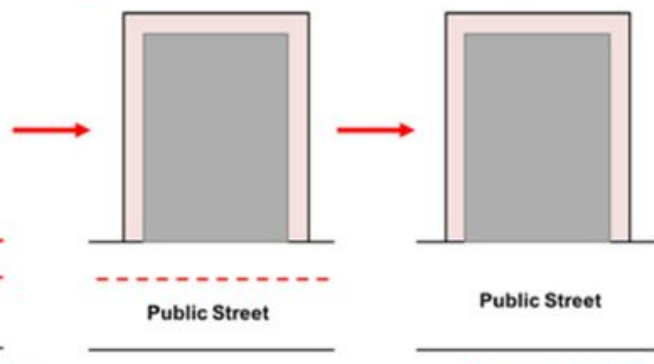

Public Street

Increasing Area in Public Realm

\section{Figure 12}

Top row (i). Graphical Representation of Regulation. (Source: Author) Second row (ii). Graphical Representation of Regulation. (Source: Author) Middle row (iii). Graphical Representation of Regulation. (Source: Author) Fourth row (iv). Graphical Representation of Regulation. (Source: Author) Bottom row (v). Graphical Representation of Regulation. (Source: Author) 